\title{
Debt Origin and Investment Efficiency from Korea
}

\author{
Heung Joo Jeon ${ }^{1}$ and Hyun Min Oh ${ }^{2, *}$ \\ 1 Department of Business Administration, DanKook University, 119 Dandae-ro, Dongnam-gu, Cheonan-si, \\ Chungcheongnam-do 31116, Korea; angel458@hanmail.net \\ 2 Department of Accounting, College of Social Sciences, National Sunchon University, 255 Jungang-ro, \\ Suncheon, Jeonnam 57922, Korea \\ * Correspondence: ohm1212@scnu.ac.kr
}

Received: 6 June 2020; Accepted: 3 August 2020; Published: 4 August 2020

\begin{abstract}
This study empirically analyzes the effect of debt origin on investment efficiency. According to previous studies that report that the quality of financial reporting may vary depending on the origin of the debt, the empirical analysis predicted that the effects of the origin of the debt on investment efficiency would be differential. Debt origin was divided into private and public debt. The analysis results of this study are as follows. First, there is a significant negative relationship between the private debt and investment efficiency, while there is a significant positive relationship between public debt and investment efficiency. This means that capital gains under public debt may be more profitable to managers by improving the quality of their accounting information than those under private debt. This is in line with the previous research which found that, when financing with public debt, the earnings management is reduced and accounting transparency is high. This study focuses on the origin of debt as a determinant of investment efficiency and analyzes the level of investment efficiency according to the origin of debt. We examine the sustainability of firms from the perspective of investment efficiency, such as raising capital and selecting optimal investment options. The results of this study suggest that the level of incentives and investment efficiency of managers may be differentiated depending on the origin of the debt.
\end{abstract}

Keywords: debt origin; public debt; private debt; investment efficiency; sustainability

\section{Introduction}

This study examines the relationship between debt origin and investment efficiency. Specifically, the purpose of this paper is to classify debt origin into public debt and private debt according to the debt procurement method, and to verify how the debt origin are related to investment efficiency. Efficient investment increases firm value, while inefficient investment lowers it. The lower the investment efficiency, the lower the earnings persistence and the less relevant of accounting earnings (Lee and Paek 2015). Firm value is defined as the present value of future cash flows. The better the future cash flow, the higher the sustainability of the firm. Corporate activities are divided into business activities, investment activities and financial activities. By selecting the optimal investment using the raised capital, the firm's value can be increased, and the firm's sustainability can be increased.

Corporate bonds are a typical form of public debt in which firms raise capital from an unspecified number of investors through capital markets. In a public debt contract, it is not easy for many investors to access the internal information of the debt issuer, which makes it difficult to grasp the future profitability or the investment risk of the debt issuer. In addition, public debt may not be controlled smoothly due to the weak monitoring system for corporate decision making and difficult negotiation required to rebalance contract conditions. Therefore, transparent financial information is expected to play a greater role for investors with a high risk of information asymmetry and benefit them more (Chun et al. 2011). 
Private debt is a contract that provides financing through a bilateral contract between a creditor and a debtor, and is a representative example of a financial institution's loan contract. Creditors of private debt can easily obtain information on the future profitability and risk prospects of the investment firm through flexible and efficient negotiation and information exchange with the firm. In addition, it is easy to cope with the uncertainty of the firm after investment because it is possible to continuously monitor the decision-making process of the firm and to exercise control through the flexible change of contract conditions. Therefore, information costs of private debt are not as large as those of public debt due to information asymmetry (Chun et al. 2011).

Private debt creditors claim to be more advantageous in terms of borrowers' information acquisition than public debt creditors (Ramakrishnan and Thakor 1984; Carey et al. 1993; Houston and James 1996; An et al. 2004). This is because private debt creditors are increasingly refinancing funds to the debtor and increasing the opportunity to acquire the private information of the borrower through accumulated monitoring over time. Since private debt creditors have a relative advantage in obtaining this information compared to public debt creditors, companies with significant information asymmetry problems tend to prefer private placement to minimize reverse selection costs. Thus, monitoring and rigorous contractual provisions of private creditors dilute this information asymmetry problem and control the potential reverse selection problem (An et al. 2004). In sum, there is a principal-agent problem between the debt-financing firm and the creditor. The cost of information asymmetry between a firm and a creditor differs depending on whether it is financed by public debt or private debt. In other words, both the firm and the creditor will try to find the optimal method of debt financing. On the other hand, investment efficiency refers to the adoption of an investment plan with positive net present value (NPV) under circumstances where there is no market friction such as reverse selection or agency cost. Thus, investment opportunities with negative NPV are classified as overinvestment and underinvestment is defined as giving up investment opportunities with positive NPV (Biddle et al. 2009; Lee and Paek 2015). In previous research, accounting information and investment efficiency are mainly examined in terms of earnings quality. Firms can reduce information asymmetry by improving earnings quality. Managers can have better investment opportunities by reducing adverse selection and moral hazard, and high earnings quality can increase investment efficiency (Biddle and Hilary 2006; McNichols and Stubben 2008; Biddle et al. 2009; Chen et al. 2011). Chen et al. (2011) reported that high earnings quality and high relevance to investment efficiency may occur in emerging countries. In addition, many previous studies have analyzed the relationship between earnings quality and investment efficiency in various perspectives. However, few studies have examined the relationship between earnings quality and investment efficiency in terms of capital procurement. Some studies have looked at the reduction of funding and debt costs (Francis et al. 2004, 2005). Bharath et al. (2008) examine the debt market's accessibility and its impact on debt contracts. This study examines the relationship between debt origin and investment efficiency in terms of debt financing.

The results of this study are as follows. First, the relationship between public debt and investment efficiency is significantly positive. These results support the hypothesis of this study. Thus, a firm that issued a public debt is more efficient than a firm that did not. As a result of analyzing the sample by the overinvestment sample and the underinvestment sample, a statistically more significant result was observed in the underinvestment sample. This is in line with previous research findings that public creditors require a high level of financial reporting quality for the debtors to reduce information asymmetry between the debtors and creditors (Chun et al. 2011; Givoly et al. 2010).

Second, the relationship between private debt and investment efficiency is significantly negative. In other words, firms that issued private debt are inefficient compared to firms that did not. As a result of analyzing the sample by the overinvestment sample and the underinvestment sample, a statistically more significant result was observed in the underinvestment sample. This allows private debt creditors to dilute this information asymmetry problem and control potential reverse selection problems with monitoring and rigorous contractual provisions (An et al. 2004). Thus, the incentive to increase the quality of financial reporting is relatively lower than that of public debt. 
This study focuses on the origin of debt as a determinant of investment efficiency and analyzes the level of investment efficiency according to debt origin. The impact on the sustainability of firms was examined according to the origin of debt during capital procurement, suggesting that the investment efficiency of firms could differ depending on the origin of debt. In other words, it is meaningful to suggest that the level of incentive and investment efficiency of managers can be differentiated, and the impact on corporate sustainability can differ depending on the origin of debt.

The rest of this study is as follows. In Section 2, the previous studies and hypotheses about the origin of debt and investment efficiency are presented. In Section 3, the research design is explained. In Section 4, we present the results of empirical analysis and in Section 5, we present the conclusion and limitations of the study.

\section{Prior Literature and Hypothesis Development}

\subsection{Debt Origin}

Previous research has argued that the role of debt is to reduce the manager's discretion and function as a check when making investment decisions (Myers 1977; Jensen 1986). D'Mello and Miranda (2010) reported that debt reduces overinvestment.

Public debt creditors have less access to the private information of a firm than private debt creditors, there are few effective ways to monitor and discipline management, and information asymmetry between managers and creditors is high (Chun et al. 2011; Givoly et al. 2010). In addition, public creditors require a high quality of financial reporting to reduce information asymmetry because financial statements are the main source of information for evaluating firms (Chun et al. 2011; Givoly et al. 2010). Public debt creditors have less access to the private information of the firm than private creditors and are less able to effectively control managers, leading to greater incentives for managers to engage in opportunistic behavior (Givoly et al. 2010). Thus, the presence of public debt may affect the quality of financial reporting.

Chun et al. (2011) examined the relationship between accrual-based earnings management and debt origin, and the relationship between earnings management through actual activities and debt origin. The results show that firms that issue public debt have lower levels of earnings management through discretionary accruals than firms that issue private debt. In addition, the degree of actual earnings management through production and expenditure activities was also low in firms which issue public debt, implying that the investors of public debt are dissolving the risks associated with information asymmetry and the lack of control over the firm through information intermediaries and that a higher level of transparent accounting information is required for public debt issuers.

Jung and Lee (2014) examined the relationship between private debt and foreign ownership. As a result, private debt and foreign ownership showed significant negative effect. In other words, foreign ownership decreased as private debt ratio increased. This implies that the higher the portion of private debt, the lower the benefit from improving the quality of accounting information.

Park (2013) analyzed the effect of debt origin on audit fees by classifying debt origin into public debt and private debt according to procurement sources and verifying the effect on audit fees. As a result, regression coefficients of private debt and public debt showed a positive direction, but only public debt was statistically significant. This result implies that the requirement of more reliable accounting information leads to the increase of audit fees in the case of public debt, where there are relatively more stakeholders rather than in private debt.

Yeo et al. (2015) analyzed the effect of public debt on the relationship between listed firms and the quality of financial reporting and found that public debt has a negative effect on the relationship between listed firms and the quality of financial reporting. This implies that the quality of financial reporting may be low in the case of firms with public debt, due to the manager's opportunistic earnings management. 
Jung (2016) examined the relationship between private debt ratio and trading volume and found that the private debt ratio and trading volume showed a positive direction. In other words, trading volume increases as the private debt ratio increases, which is interpreted to be the result of an increase in the level of disagreement among investors.

In sum, public debt is a strong incentive to raise the quality of accounting earnings as a part of solving the information asymmetry problem between firms and external investors.

\subsection{Investment Efficiency}

Investment efficiency is judged to be efficient if the company makes a normal investment as expected, if the company invests normally. However, if the actual investment level is greater (overinvestment) or smaller (underinvestment) compared to the expected investment level, it is judged that the company's investment is inefficient. Biddle et al. (2009) defined a company's investment to be efficient if the company makes an investment with a positive net present value (NPV) based on the results of previous studies.

Park and Bae (2011) verified that the quality of financial reporting and corporate governance reduce overinvestment and underinvestment in firms from a previous study which found that the higher the quality of financial reporting, the better the investment efficiency. The analysis showed that the quality of financial reporting increases the investment of firms with potential for underinvestment, but has little effect on the decrease in investment of firms with potential for overinvestment. These results indicate that the quality of financial reporting does not completely eliminate investment inefficiency, but the quality of financial reporting moderates the information asymmetry. In addition, verifying the effects of corporate governance (an audit committee, the major shareholder ratio, the foreign ownership ratio) on overinvestment and underinvestment yielded inconsistent results. Therefore, it can be seen that corporate governance does not completely reduce the inefficient investment of the firm.

Lee and Paek (2015) analyzed the effect of corporate investment efficiency on earnings persistence and value relevance. Efficient investment will increase firm value, while inefficient investment will decrease firm value. When the firm's actual investment level is outside the expected investment level, the lower the investment efficiency, the lower earnings persistence and the lower the relevance of the accounting earnings. As a result, the more inefficient a firm's investment behavior, the lower the earnings persistence and value relevance.

With a higher quality of accounting information, the lesser information asymmetry will reduce market anomalies which reduces managerial opportunistic behavior (Lee 2009). Firms that borrow debt as public debt have a higher probability of high earnings quality than those that do not. Many previous studies have argued that the better the earnings quality, the better the investment efficiency. In terms of the relationship between debt origin and investment efficiency, public debt may act as a mechanism to solve information asymmetry problems for firms and external investors. If the information asymmetry problem is solved by improving the earnings quality, it will lead to efficient investment. Private debt has less incentive to improve the earnings quality than public debt. The shares of private/public debt in the total debt holding of firms or the actual levels in $\mathrm{H} 1 / \mathrm{H} 2$ are relative shares. Accordingly, if the debt is raised by private debt rather than public debt, the investment efficiency is expected to be lower than that of public debt. Therefore, the hypotheses that verify the relationship between debt origin and investment efficiency is as follows.

Hypothesis 1 (H1). Private debt and investment efficiency have a negative relationship.

Hypothesis 2 (H2). Public debt and investment efficiency have a positive relationship. 


\section{Research Design}

\subsection{Data and Sample}

The sample consists of listed companies from 2002 to 2017. Information on financial data was collected from FN Data-Guide provided by the Financial Information and Solution Co., Ltd. (Seoul, Korea) and TS-2000 database provided by Korea Listed Companies Association. We set the sample period after the foreign exchange crisis. Investment efficiency, which is a dependent variable, is $t+1$, and independent variable is $t$, so the analysis period is until 2017, which is available.

Table 1 shows the sample selection process. The reason the financial industry is excluded from the sample in the sample selection criterion is that the accounting treatment of these companies is different from other companies and homogeneity of the sample cannot be secured. There are differences in the components of the financial statements, and even the same account subjects have different meanings from other industries. Those firms whose year-ends are not on 31 December are excluded because of data homogeneity. In this analysis, observations with anomalies of $1 \%$ and $99 \%$ of the distribution of each variable were winsorized. The final sample used in this study is 8754 firm-year observations.

Table 1. Sample selection.

\begin{tabular}{cc}
\hline Sample Selection Criteria & Firm-Year Observations \\
\hline Firms listed in the Korea Exchange 2002 to 2017 & 9977 \\
\hline (less) Firms with fiscal year end except December and financial firms & $(793)$ \\
\hline (less) Financial and stock data cannot collect from FN Data-Guide & $(430)$ \\
\hline Final sample & 8754 \\
\hline
\end{tabular}

Table 2 shows the distribution of the sample by year and industry. Panel A of Table 2 shows the distribution of the sample by year. Although the number of listed companies has been on an increasing trend by year, there has not been a large variation in the period. Panel B of Table 2 shows the industry distribution of the sample. In the model estimated by Chen et al. (2011), the residual means investment inefficiency. In Chen et al. (2011)'s model, the residual means investment inefficiency. The sample is an overinvestment if the residual is greater than 0 and an underinvestment if the residual is less than zero.

Table 2. Distributions over the sample period.

\begin{tabular}{|c|c|c|c|c|c|c|}
\hline \multirow{3}{*}{ Year } & \multicolumn{4}{|c|}{ Panel A: Distribution of Sample by Year } & \multirow{2}{*}{\multicolumn{2}{|c|}{ Underinvestment Sample }} \\
\hline & \multicolumn{2}{|c|}{ Total Sample } & \multicolumn{2}{|c|}{ Overinvestment Sample } & & \\
\hline & Frequency & Percent (\%) & Frequency & Percent (\%) & Frequency & Percent (\%) \\
\hline 2002 & 413 & 4.72 & 178 & 4.96 & 235 & 4.74 \\
\hline 2003 & 433 & 4.95 & 182 & 4.79 & 251 & 5.06 \\
\hline 2004 & 448 & 5.12 & 172 & 4.53 & 276 & 5.57 \\
\hline 2005 & 465 & 5.31 & 214 & 5.64 & 251 & 5.06 \\
\hline 2006 & 485 & 5.54 & 208 & 5.48 & 277 & 5.59 \\
\hline 2007 & 500 & 5.71 & 208 & 5.48 & 292 & 5.89 \\
\hline 2008 & 521 & 5.95 & 179 & 4.71 & 342 & 6.90 \\
\hline 2009 & 540 & 6.17 & 249 & 6.56 & 291 & 5.87 \\
\hline 2010 & 567 & 6.48 & 249 & 6.56 & 318 & 6.42 \\
\hline 2011 & 592 & 6.76 & 263 & 6.93 & 328 & 6.62 \\
\hline 2012 & 600 & 6.85 & 253 & 6.66 & 347 & 7.00 \\
\hline 2013 & 610 & 6.97 & 287 & 7.56 & 323 & 6.52 \\
\hline
\end{tabular}


Table 2. Cont.

\begin{tabular}{|c|c|c|c|c|c|c|}
\hline 2014 & 618 & 7.06 & 251 & 6.61 & 367 & 7.41 \\
\hline 2015 & 636 & 7.27 & 297 & 7.82 & 339 & 6.84 \\
\hline 2016 & 652 & 7.45 & 315 & 8.30 & 337 & 6.80 \\
\hline 2017 & 674 & 7.70 & 293 & 7.69 & 382 & 7.71 \\
\hline Total & 8754 & 100 & 3798 & 100 & 4956 & 100 \\
\hline \multicolumn{7}{|c|}{ Panel B: Distribution of Sample by Industry } \\
\hline \multirow{2}{*}{ Industry } & \multicolumn{2}{|c|}{ Total Sample } & \multicolumn{2}{|c|}{ Overinvestment Sample } & \multicolumn{2}{|c|}{ Underinvestment Sample } \\
\hline & Frequency & Percent (\%) & Frequency & Percent (\%) & Frequency & Percent (\%) \\
\hline Food, Beverage & 447 & 5.11 & 188 & 4.95 & 258 & 5.21 \\
\hline Fiber, Clothes, Leathers & 341 & 3.90 & 171 & 4.50 & 170 & 3.43 \\
\hline Timber, Pulp, Furniture & 364 & 4.16 & 151 & 3.98 & 213 & 4.30 \\
\hline Cokes, Chemical & 963 & 11.00 & 421 & 11.09 & 542 & 10.94 \\
\hline Medical Manufacturing & 432 & 4.93 & 171 & 4.50 & 261 & 5.27 \\
\hline Rubber and Plastic & 295 & 3.37 & 130 & 3.42 & 165 & 3.33 \\
\hline Non Metallic & 272 & 3.11 & 109 & 2.87 & 163 & 3.29 \\
\hline Metallic & 739 & 8.44 & 309 & 8.14 & 430 & 8.68 \\
\hline PC, Medical & 602 & 6.88 & 260 & 6.85 & 342 & 6.90 \\
\hline Machine and Electronic & 617 & 7.05 & 240 & 6.32 & 377 & 7.61 \\
\hline Other Transportation & 657 & 7.51 & 286 & 7.53 & 371 & 7.49 \\
\hline Construction & 431 & 4.92 & 205 & 5.40 & 226 & 4.56 \\
\hline Retail and Whole Sales & 715 & 8.17 & 312 & 8.22 & 403 & 8.13 \\
\hline Transportation Service & 298 & 3.40 & 130 & 3.42 & 168 & 3.39 \\
\hline Professional Services & 793 & 9.06 & 424 & 11.17 & 369 & 7.45 \\
\hline Other & 788 & 9.00 & 291 & 7.64 & 498 & 10.05 \\
\hline Total & 8754 & 100 & 3798 & 100 & 4956 & 100 \\
\hline
\end{tabular}

\subsection{Methodology}

In this study, the regression model for testing the effect of the debt origin on the investment efficiency is shown in Equations (1) and (3). Equations (1) and (3) apply the methodology of Chun et al. (2011). Debt origin was verified by dividing debt ratio (total loans/total assets), bond ratio (bonds/total assets), and the bond dummy variable. Equation (2) applies the methodology of Jung and Lee (2014). Debt origin is divided into public debt ratio and public debt is divided by the sum of public debt and private debt.

$$
\begin{aligned}
& I N V_{-} E F_{i t+1}=\beta_{0}+\beta_{1} L O A N R_{i t}+\beta_{2} B_{O N D R}+\beta_{3} S_{I Z E_{i t}}+\beta_{4} L E V_{i t}+\beta_{5} L O S S D U M_{i t} \\
& +\beta_{6} T A_{i t}+\beta_{7} S T D_{-} O C F_{i t}+\beta_{8} A G E_{i t}+\beta_{9} S L A C K_{i t}+\beta_{10} O W N_{i t} \\
& +\beta_{11} F O R_{i t}+\beta_{12} B_{I G} 4_{i t}+\sum Y D+\sum I D+\varepsilon_{i t} \\
& I N V_{-} E F_{i t+1}=\beta_{0}+\beta_{1} B O N D_{-} L O A N_{i t}+\beta_{2} S I Z E_{i t}+\beta_{3} L E V_{i t}+\beta_{4} L O S S D U M_{i t}+\beta_{5} T A_{i t} \\
& +\beta_{6} S T D \_O C F_{i t}+\beta_{7} A G E_{i t}+\beta_{8} S L A C K_{i t}+\beta_{9} O W N_{i t}+\beta_{10} F O R_{i t} \\
& +\beta_{11} B_{I G} 4_{i t}+\sum Y D+\sum I D+\varepsilon_{i t} \\
& I N V_{-} E F_{i t+1}=\beta_{0}+\beta_{1} L O A N R_{i t}+\beta_{2} B_{O N D D U M}+\beta_{3} S I Z E_{i t}+\beta_{4} L E V_{i t} \\
& +\beta_{5} L_{O S S D U M}+\beta_{6} T A_{i t}+\beta_{7} S T D_{-} O C F_{i t}+\beta_{8} A G E_{i t}+\beta_{9} S L A C K_{i t} \\
& +\beta_{10} O W N_{i t}+\beta_{11} F O R_{i t}+\beta_{12} B I G 4_{i t}+\sum Y D+\sum I D+\varepsilon_{i t}
\end{aligned}
$$

where the dependent variable, investment efficiency, is measured as was done by Chen et al. (2011) and is defined as the absolute value of the estimated residual multiplied by -1 . The closer the residual is to zero, 
the better the investment, and the farther the residual is from zero, the more inefficient the investment. Investment efficiency is generally based on the methodologies of McNichols and Stubben (2008); Biddle et al. (2009); and Chen et al. (2011). In this study, the methodologies of Biddle et al. (2009) and Chen et al. (2011) were applied. In Equation (1), LOANR is measured by dividing borrowings by total assets. BOND is measured by BONDR.

In Equation (1), LOANR and BONDR are the variables of interest in this study. The predictive sign of $L O A N R$ is in the negative direction, and the predictive sign of BONDR is in the positive direction. In Equation (2), BOND_LOAN is the public debt ratio, which is measured by dividing public debt by the sum of public debt and private debt. The predictive sign of BOND_LOAN is in the positive direction. In Equation (3), LOANR and BONDDUM are the variables of interest in this study. The predictive sign of LOANR is in the negative direction and the predictive sign of BONDDUM is in the positive direction. The control variables are SIZE, LEV, LOSSDUM, TA, STD_OCF, AGE, SLACK, OWN, FOR and BIG4. $S I Z E$ is the size of the firm and is determined by taking the natural logarithm of the firm's total assets.

$L E V$ represents leverage or capital structure as the debt ratio of a firm. LOSSDUM is a loss dummy variable, which is 1 for a loss firm and 0 otherwise. TA is the tangible asset ratio, which is the firm's tangible asset divided by its total assets. STD_OCF is the standard deviation of dividing operating cash flow from the cash flow statement for five years from $t-4$ to $t$ by the lagged total assets. AGE is the value obtained by taking the natural logarithm of the age of firm. SLACK is the ratio of cash divided by total assets, OWN is the ownership ratio of major shareholder, and FOR is the ratio of foreign ownership. BIG4 is a dummy variable that is 1 if the auditor is a BIG4 accounting firm and 0 otherwise. $Y D$ is year dummy and ID is industry dummy.

The control variables were set with reference to the previous studies (Biddle et al. 2009; Chen et al. 2011; Cho and Kang 2016). We added variables to control the size of firm (SIZE) and the debt ratio $(L E V)$. In addition, we included in the control variables the effects of LOSSDUM, volatility of operating cash flow (STD_OCF), and AGE on investment efficiency (Biddle et al. 2009; Richardson 2006).

The degree of cash holdings (SLACK) included the ability to raise funds for capital investment, while the tangible asset ratio (TA) included the tangible asset ratio $(T A)$ to control the impact of past levels of capital investment (Biddle et al. 2009; Cho and Kang 2016). In addition, to control the effect of corporate governance on investment efficiency, the control variable was selected as the major shareholder $(O W N)$ and foreign ownership (FOR). In addition, industry-specific dummies (ID) are included to control industry-specific characteristics. Please refer to Appendix A for a summary of variables.

In this study, we used the method of Chen et al. (2011) as a proxy for investment efficiency. In the model estimated by the following equation, the residual means investment inefficiency. The sample is an overinvestment if the residual is greater than 0 and an underinvestment if the residual is less than zero. In this study, the absolute value of residuals is used to analyze the magnitude of investment efficiency. We also used the value multiplied by -1 to match the direction of the interest variable and the dependent variable. Thus, the greater value means that investment is more efficient.

$$
I N V E S T_{i t}=\beta_{0}+\beta_{1} N E G_{i t-1}+\beta_{2} G R W_{i t-1}+\beta_{3} N E G_{i t-1} \times G R W_{i t-1}+\varepsilon_{i t}
$$

where INVEST $T_{i t}$ is the sum of new investment in machinery, equipment, vehicles, land, buildings, and research and development expenditures, less the sale of fixed assets, and scaled by lagged total assets for firm $i$ in year $t$ (property, plant and equipment at the end of year $t$ - property, plant and equipment at the beginning of year $t+$ depreciation expense + losses on disposal of fixed assets - gains on disposal of fixed assets + research and development expenditures)/beginning total asset. $N E G_{i t}$ takes the value of 1 for negative revenue growth, and 0 otherwise. GRW it is the annual revenue growth rate for firm $i$ in year $t-1$ (sales for firm $i$ in year $t-1$ sales for firm $i$ in year $t-2$ )/sales for firm $i$ in year $t-2$. $\varepsilon_{i t}$ is the residual. 


\section{Empirical Results}

Panel A in Table 3 shows the descriptive statistics of the main variables for total samples. Since the debt ratio $(L E V)$, corporate size (SIZE), tangible asset ratio $(T A)$, and major shareholder equity $(O W N)$ exhibit no significant difference between the mean and the median, it can be assumed that they are close to a normal distribution.

Table 3. Descriptive statistics.

\begin{tabular}{|c|c|c|c|c|c|c|c|c|}
\hline \multirow[b]{2}{*}{ Variable } & \multicolumn{8}{|c|}{ Panel A Total Sample $(\mathrm{n}=8754)$} \\
\hline & $\mathbf{n}$ & Mean & Std. Dev. & Min & $\begin{array}{c}\text { 25th } \\
\text { Percentile }\end{array}$ & Median & $\begin{array}{c}\text { 75th } \\
\text { Percentile }\end{array}$ & Max \\
\hline INV_EF & 8754 & -0.051 & 0.062 & -0.330 & -0.061 & -0.030 & -0.013 & 0.000 \\
\hline LOANR & 8754 & 0.242 & 0.175 & 0.000 & 0.094 & 0.233 & 0.365 & 1.118 \\
\hline BONDR & 8754 & 0.032 & 0.057 & 0.000 & 0.000 & 0.000 & 0.045 & 0.520 \\
\hline BOND_LOANR & 8754 & 0.081 & 0.124 & 0.000 & 0.000 & 0.000 & 0.151 & 0.500 \\
\hline BONDDUM & 8754 & 0.380 & 0.485 & 0.000 & 0.000 & 0.000 & 1.000 & 1.000 \\
\hline SIZE & 8754 & 26.617 & 1.489 & 23.649 & 25.575 & 26.368 & 27.432 & 30.783 \\
\hline LEV & 8754 & 0.464 & 0.255 & 0.010 & 0.281 & 0.454 & 0.612 & 2.140 \\
\hline LOSSDUM & 8754 & 0.200 & 0.400 & 0.000 & 0.000 & 0.000 & 0.000 & 1.000 \\
\hline $\mathrm{TA}$ & 8754 & 0.339 & 0.358 & 0.000 & 0.175 & 0.319 & 0.461 & 2.033 \\
\hline STD_OCF & 8754 & 0.143 & 0.083 & 0.030 & 0.086 & 0.125 & 0.177 & 0.525 \\
\hline AGE & 8754 & 2.727 & 0.879 & 0.000 & 2.303 & 2.944 & 3.367 & 4.111 \\
\hline SLACK & 8754 & 0.056 & 0.064 & 0.000 & 0.012 & 0.036 & 0.077 & 0.850 \\
\hline OWN & 8754 & 0.428 & 0.164 & 0.073 & 0.310 & 0.428 & 0.539 & 0.840 \\
\hline FOR & 8754 & 0.101 & 0.139 & 0.000 & 0.006 & 0.037 & 0.145 & 0.620 \\
\hline BIG4 & 8754 & 0.645 & 0.479 & 0.000 & 0.000 & 1.000 & 1.000 & 1.000 \\
\hline
\end{tabular}

Notes: (1) This table presents the descriptive statistics for the variables used in the regression analyses. INV_EF $=$ investment efficiency, the absolute value of the residual measured as Chen et al. (2011) multiplied by $(-1)$ for firm $i$ in year $t+1$; LOANR $=$ loan ratio, lonar is measured by dividing borrowings by total assets for firm $i$ in year $t$; BONDR $=$ bond ratio, bondr is measured by dividing bonds by total assets for firm $i$ in year $t$; BONDDUM = bond dummy variable, 1 if the firm issued bond, and 0 otherwise for firm $i$ in year $t$; BOND_LOAN $=$ the public debt ratio, which is measured by dividing public debt by the sum of public debt and private debt for firm $i$ in year $t$; SIZE $=$ firm size, the natural logarithm of total assets for firm $i$ in year $t$; LEV = debt ratio for firm $i$ in year $t$, (total debt/total assets); LOSSDUM = loss dummy variable, 1 if the firm reported negative net income, and 0 otherwise for firm $i$ in year $t$; TA $=$ tangible asset ratio for firm $i$ in year $t$, (property + plant + equipment/total assets); STD_OCF $=$ the standard deviation of operating cash flows, the standard deviation of operating cash flows for five years from period $t-4$ to period $t$; AGE $=$ the natural logarithm of firm age for firm $i$ in year $t$; SLACK $=$ cash ratio, cash/total assets; $\mathrm{OWN}=$ the ownership ratio, the largest shareholders ownership for firm $i$ in year $t$; FOR $=$ the foreign ownership ratio, foreign ownership for firm $i$ in year $t$; BIG4 = big4 auditor, 1 if an annual financial statement is audited by a big4 auditor, and 0 otherwise. (2) Please refer to Section 3.2 for variable definitions.

Table 4 shows the Pearson correlation analysis results of the main variables. Investment efficiency has a significant negative relationship with LOANR, LEV, LOSSDUM, TA and STD_OCF. This means that the more a firm is financed by private debt, the higher its debt ratio, the more negative its negative income, the greater its tangible assets and the greater the volatility of its operating cash flows, the lower the investment efficiency of firm. Investment efficiency has a significant positive relationship with BONDR, BOND_LOANR, BONDDUM, SIZE, AGE, SLACK, OWN, FOR, BIG4. This means that the greater degree of financing through public debt, the larger the firm size, the older the firm, the higher the level of cash reserves, the higher the shareholding ratio and foreign ownership ratio, and if a company is audited by a big4 accounting firm, the greater the investment efficiency. These results were obtained without controlling the effects of other variables on investment efficiency. Therefore, multivariate regression analysis was performed, including several control variables. 
Table 4. Pearson correlations $(\mathrm{n}=8754)$.

\begin{tabular}{|c|c|c|c|c|c|c|c|c|c|c|c|c|c|c|}
\hline & (1) & (2) & (3) & (4) & (5) & (6) & (7) & (8) & (9) & (10) & (11) & (12) & (13) & (14) \\
\hline \multicolumn{15}{|l|}{ (1) INV_EF } \\
\hline (2) LOANR & $\underset{* * *}{-0.051}$ & & & & & & & & & & & & & \\
\hline (3) BONDR & $\underset{* * *}{0.008}$ & $\begin{array}{c}0.392 \\
* * *\end{array}$ & & & & & & & & & & & & \\
\hline (4) BOND_LOANR & $\underset{* * *}{0.016}$ & $\begin{array}{c}0.187 \\
* * *\end{array}$ & 0.873 & & & & & & & & & & & \\
\hline (5) BONDDUM & $\underset{* *}{0.020}$ & 0.395 & $\begin{array}{c}0.707 \\
* * * \\
\end{array}$ & $\begin{array}{c}0.790 \\
* * *\end{array}$ & & & & & & & & & & \\
\hline (6) SIZE & $\underset{* * *}{0.070}$ & 0.130 & 0.395 & $\begin{array}{c}0.448 \\
* * *\end{array}$ & $\begin{array}{c}0.482 \\
* * *\end{array}$ & & & & & & & & & \\
\hline (7) LEV & -0.043 & $\begin{array}{c}0.570 \\
* * *\end{array}$ & $\begin{array}{c}0.267 \\
* * * \\
\end{array}$ & $\begin{array}{c}0.169 \\
* * *\end{array}$ & $\begin{array}{c}0.291 \\
* * *\end{array}$ & $\begin{array}{c}0.171 \\
* * *\end{array}$ & & & & & & & & \\
\hline (8) LOSSDUM & $\underset{* * *}{-0.049}$ & $\underset{* * * *}{0.300}$ & $\underset{* * *}{0.052}$ & $\begin{array}{c}-0.027 \\
* *\end{array}$ & $\begin{array}{c}0.047 \\
* * *\end{array}$ & $\underset{* * *}{-0.132}$ & 0.162 & & & & & & & \\
\hline (9) TA & $\begin{array}{c}-0.083 \\
* * * \\
\end{array}$ & 0.120 & $\begin{array}{c}0.070 \\
* * * \\
\end{array}$ & $\begin{array}{l}0.038 \\
* * * \\
\end{array}$ & $\begin{array}{l}0.046 \\
* * * \\
\end{array}$ & 0.086 & $\begin{array}{c}0.321 \\
* * * \\
\end{array}$ & -0.010 & & & & & & \\
\hline (10) STD_OCF & $\underset{* * *}{-0.062}$ & $\underset{* * *}{-0.052}$ & -0.005 & 0.003 & $\begin{array}{l}-0.020 \\
*\end{array}$ & -0.071 & $\begin{array}{c}0.034 \\
* * * \\
\end{array}$ & $\begin{array}{c}0.048 \\
* * *\end{array}$ & $\begin{array}{c}-0.026 \\
* *\end{array}$ & & & & & \\
\hline (11) AGE & $\underset{*}{0.014}+{ }^{*}$ & $\begin{array}{c}0.082 \\
* * *\end{array}$ & 0.004 & -0.012 & $\begin{array}{c}0.054 \\
* * *\end{array}$ & $\begin{array}{l}0.059 \\
* * * \\
\end{array}$ & 0.004 & $\begin{array}{l}0.083 \\
* * * \\
\end{array}$ & $\begin{array}{l}0.032 \\
* * * \\
\end{array}$ & -0.103 & & & & \\
\hline (12) SLACK & $\underset{* *}{0.018}$ & $\underset{* * *}{-0.277}$ & $\begin{array}{l}-0.058 \\
* * * \\
\end{array}$ & 0.006 & $\underset{* * *}{-0.102}$ & -0.085 & $\underset{* * *}{-0.101}$ & $\underset{* * *}{-0.062}$ & $\underset{* * *}{-0.134}$ & $\underset{* * *}{0.071}$ & $\underset{* * *}{-0.080}$ & & & \\
\hline (13) OWN & $\underset{* *}{0.027}$ & $\underset{* * *}{-0.089}$ & $\begin{array}{c}-0.109 \\
* * *\end{array}$ & $\underset{* * *}{-0.112}$ & -0.135 & $\begin{array}{c}-0.065 \\
* * *\end{array}$ & $\underset{* * *}{-0.118}$ & $\underset{* * *}{-0.131}$ & -0.001 & -0.076 & $\underset{* * *}{-0.128}$ & $\underset{* * *}{-0.077}$ & & \\
\hline (14) FOR & $\underset{* *}{0.016}$ & $\underset{* * *}{-0.197}$ & $\begin{array}{c}0.150 \\
* * * \\
\end{array}$ & $\begin{array}{c}0.266 \\
* * * \\
\end{array}$ & 0.168 & $\underset{* * *}{0.492}$ & $\underset{* * *}{-0.073}$ & $\underset{* * *}{-0.167}$ & $\underset{* * *}{0.035}$ & $\underset{*}{0.016}$ & -0.025 & $\begin{array}{c}0.093 \\
* * * \\
\end{array}$ & $\underset{* * *}{-0.163}$ & \\
\hline (15) BIG4 & $\underset{* *}{0.025}$ & 0.004 & $\begin{array}{c}0.153 \\
* * * *\end{array}$ & $\underset{* * *}{0.182}$ & $\underset{* * *}{0.176}$ & $\begin{array}{c}0.400 \\
* * *\end{array}$ & $\underset{* * *}{0.034}$ & $\underset{* * *}{-0.080}$ & -0.007 & $\begin{array}{c}-0.019 \\
*\end{array}$ & $\underset{* * *}{-0.053}$ & $\underset{* *}{0.018}$ & $\begin{array}{c}0.038 \\
* * *\end{array}$ & $\begin{array}{c}0.252 \\
* * *\end{array}$ \\
\hline
\end{tabular}

Notes: (1) This table presents the Pearson correlations for the variables used in the regression analyses. (2) Please refer to Section 3.2 for variable definitions. (3) ${ }^{* * *}, * * * *$ denote significance at the $1 \%, 5 \%$, and $10 \%$ levels, respectively (two-tailed).

\subsection{Multivariate Results}

Table 5 shows the results of the regression analysis of Equations (1)-(3) on the relationship between debt origin and investment efficiency for the total sample. We considered Model 1 to be the most appropriate for examining the debt origin-investment efficiency link. It is a model that has often been used in previous studies, and is generally scaled with total assets. We provided results of other models as robustness checks. The $\mathrm{F}$ value of the analysis result is statistically significant, indicating that the research model is appropriate. The VIF of the independent variable used in the regression analysis of this study was less than 3 and did not exceed 10, indicating that the problem of multicollinearity is not serious.

In Model 1, the LOANR and investment efficiency were significant in the negative direction at the $5 \%$ level. In addition, BONDR and investment efficiency were significant in the positive direction at the $1 \%$ level. This means that firms that have made a large amount of financing through loans, which is private debt, have low investment efficiency. Firms that have sourced a lot of financing by issuing public debt have a high investment efficiency. In Model 2, BOND_LOANR and investment efficiency, defined as the share of public debt in the total of public and private debt, were statistically significant. In Model 3, the LOANR and investment efficiency were significant in the negative direction at the 5\% level, and the public debt and investment efficiency were defined as dummy variables. The relationship between BONDDUM and investment efficiency showed a significant in the positive direction at the $1 \%$ level. 
Table 5. Debt origin and investment efficiency: total sample $(n=8754)$.

\begin{tabular}{|c|c|c|c|c|c|c|}
\hline \multirow[b]{2}{*}{ Variables } & \multicolumn{2}{|c|}{ Model 1} & \multicolumn{2}{|c|}{ Model 2} & \multicolumn{2}{|c|}{ Model 3} \\
\hline & $\begin{array}{c}\text { Coeff. } \\
\text { (t-Value) }\end{array}$ & $\begin{array}{c}p \text {-Value } \\
\text { VIF }\end{array}$ & $\begin{array}{c}\text { Coeff. } \\
\text { (t-Value) }\end{array}$ & $\begin{array}{c}p \text {-Value } \\
\text { VIF }\end{array}$ & $\begin{array}{c}\text { Coeff. } \\
\text { (t-Value) }\end{array}$ & $\begin{array}{c}p \text {-Value } \\
\text { VIF }\end{array}$ \\
\hline \multirow{2}{*}{ INTERCEPT } & 0.069 & 0.001 & 0.057 & 0.007 & 0.096 & $<0.0001$ \\
\hline & $(3.400)^{* * *}$ & 0.000 & $(2.710)^{* * *}$ & 0.000 & $(4.630)^{* * *}$ & 0.000 \\
\hline \multirow{2}{*}{ LOANR } & -0.012 & 0.029 & & & -0.015 & 0.036 \\
\hline & $(-2.180)^{* *}$ & 2.203 & & & $(-2.100)^{* *}$ & 2.161 \\
\hline \multirow{2}{*}{ BONDR } & 0.102 & $<0.0001$ & & & & \\
\hline & $(5.850)^{* * *}$ & 1.436 & & & & \\
\hline \multirow{2}{*}{ BOND_LOANR } & & & 0.039 & $<0.0001$ & & \\
\hline & & & $(4.940)^{* * *}$ & 1.337 & & \\
\hline \multirow{2}{*}{ BONDDUM } & & & & & 0.017 & $<0.0001$ \\
\hline & & & & & $(8.020)^{* * *}$ & 1.612 \\
\hline \multirow{2}{*}{ SIZE } & -0.007 & $<0.0001$ & -0.006 & $<0.0001$ & -0.008 & $<0.0001$ \\
\hline & $(-8.470)^{* *}$ & 1.975 & $(-7.590) * * *$ & 2.053 & $(-9.610)^{* * *}$ & 2.118 \\
\hline \multirow{2}{*}{ LEV } & 0.017 & $<0.0001$ & 0.015 & 0.000 & 0.016 & $<0.0001$ \\
\hline & $(3.630) * * *$ & 2.011 & $(3.600)^{* * *}$ & 1.386 & $(3.330)^{* * *}$ & 2.013 \\
\hline \multirow{2}{*}{ LOSSDUM } & -0.019 & $<0.0001$ & -0.020 & $<0.0001$ & -0.019 & $<0.0001$ \\
\hline & $(-8.480)^{* * *}$ & 1.202 & $(-8.950)^{* * *}$ & 1.134 & $(-8.530)^{* * *}$ & 1.202 \\
\hline \multirow{2}{*}{ TA } & -0.009 & 0.065 & -0.009 & 0.054 & -0.006 & 0.165 \\
\hline & $(-1.850)^{*}$ & 1.450 & $(-1.930) *$ & 1.456 & $(-1.390)$ & 1.454 \\
\hline \multirow{2}{*}{ STD_OCF } & 0.082 & $<0.0001$ & 0.087 & $<0.0001$ & 0.083 & $<0.0001$ \\
\hline & $(7.600)^{* * *}$ & 1.166 & $(7.750)^{* * *}$ & 1.164 & $(7.630)^{* * *}$ & 1.166 \\
\hline \multirow{2}{*}{ AGE } & -0.005 & $<0.0001$ & -0.005 & $<0.0001$ & -0.005 & $<0.0001$ \\
\hline & $(-4.880)^{* * *}$ & 1.113 & $(-4.420)^{* * *}$ & 1.104 & $(-5.100)^{* * *}$ & 1.110 \\
\hline \multirow{2}{*}{ SLACK } & -0.039 & 0.006 & -0.052 & 0.001 & -0.036 & 0.012 \\
\hline & $(-2.770)^{* * *}$ & 1.188 & $(-3.390) * * *$ & 1.107 & $(-2.520)^{* *}$ & 1.183 \\
\hline \multirow{2}{*}{ OWN } & -0.025 & $<0.0001$ & -0.023 & $<0.0001$ & -0.023 & $<0.0001$ \\
\hline & $(-4.510)^{* * *}$ & 1.203 & $(-4.030)^{* * *}$ & 1.209 & $(-4.140)^{* * *}$ & 1.208 \\
\hline \multirow{2}{*}{ FOR } & 0.026 & 0.001 & 0.023 & 0.004 & 0.027 & 0.000 \\
\hline & $(3.390)^{* * *}$ & 1.601 & $(2.900) * * *$ & 1.603 & $(3.630)^{* * *}$ & 1.601 \\
\hline \multirow{2}{*}{ BIG4 } & 0.001 & 0.580 & 0.001 & 0.696 & 0.001 & 0.541 \\
\hline & $(0.580)$ & 1.253 & $(0.390)$ & 1.253 & $(0.610)$ & 1.253 \\
\hline YD & \multicolumn{2}{|c|}{ Included } & \multicolumn{2}{|c|}{ Included } & \multicolumn{2}{|c|}{ Included } \\
\hline ID & \multicolumn{2}{|c|}{ Included } & \multicolumn{2}{|c|}{ Included } & \multicolumn{2}{|c|}{ Included } \\
\hline F-VALUE & \multicolumn{2}{|c|}{$43.18^{* * *}$} & \multicolumn{2}{|c|}{$41.42^{* * *}$} & \multicolumn{2}{|c|}{$44.18^{* * *}$} \\
\hline ADJ R-SQ & & & & & & \\
\hline
\end{tabular}

Notes: (1) This table presents the results from regressing debt origin on investment efficiency for total sample. Models 1, 2, and 3 are classified as follows. Model 1 scaled public and private debts to total assets, and model 2 scaled public and private debts to the sum of public and private debts. Model 3 looks at public debt as dummy variable rather than continuous variable. (2) Please refer to Section 3.2 for variable definitions. (3) ***,*** denote significance at the $1 \%, 5 \%$, and $10 \%$ levels, respectively (two-tailed).

Table 6 shows the results of the regression analysis of Equations (1)-(3) on the relationship between debt origin and investment efficiency for the overinvestment sample. In Model 1, the LOANR and investment efficiency were not statistically significant. The relationship between BONDR and investment efficiency showed a positive direction, but was not statistically significant. In Model 2, BOND_LOANR and investment efficiency, defined as the share of public debt in the total of public and private debt, were not statistically significant. In Model 3, the LOANR and investment efficiency were not statistically significant, and the public debt and investment efficiency were defined as dummy variables. The relationship between BONDDUM and investment efficiency showed a positive direction, but was not statistically significant. 
Table 6. Debt origin and investment efficiency: overinvestment sample $(n=3798)$.

\begin{tabular}{|c|c|c|c|c|c|c|}
\hline \multirow[b]{2}{*}{ Variables } & \multicolumn{2}{|c|}{ Model 1} & \multicolumn{2}{|c|}{ Model 2} & \multicolumn{2}{|c|}{ Model 3} \\
\hline & $\begin{array}{c}\text { Coeff. } \\
\text { (t-Value) }\end{array}$ & $\begin{array}{c}p \text {-Value } \\
\text { VIF }\end{array}$ & $\begin{array}{c}\text { Coeff. } \\
\text { (t-Value) }\end{array}$ & $\begin{array}{c}p \text {-Value } \\
\text { VIF }\end{array}$ & $\begin{array}{c}\text { Coeff. } \\
\text { (t-Value) }\end{array}$ & $\begin{array}{c}p \text {-Value } \\
\text { VIF }\end{array}$ \\
\hline INTERCEPT & $\begin{array}{c}-0.158 \\
(-5.770)^{* * *}\end{array}$ & $\begin{array}{c}<0.0001 \\
0.000\end{array}$ & $\begin{array}{c}-0.162 \\
(-5.800)^{* * *}\end{array}$ & $\begin{array}{c}<0.0001 \\
0.000\end{array}$ & $\begin{array}{c}-0.146 \\
(-5.200)^{* * *}\end{array}$ & $\begin{array}{c}<0.0001 \\
0.000\end{array}$ \\
\hline LOANR & $\begin{array}{c}-0.010 \\
(-1.080)\end{array}$ & $\begin{array}{l}0.281 \\
2.177\end{array}$ & & & $\begin{array}{c}-0.013 \\
(-1.380)\end{array}$ & $\begin{array}{l}0.168 \\
2.120\end{array}$ \\
\hline BONDR & $\begin{array}{c}0.004 \\
(0.180)\end{array}$ & $\begin{array}{l}0.859 \\
1.585\end{array}$ & & & & \\
\hline BOND_LOANR & & & $\begin{array}{l}-0.010 \\
(-1.000)\end{array}$ & $\begin{array}{l}0.318 \\
1.439\end{array}$ & & \\
\hline BONDDUM & & & & & $\begin{array}{c}0.004 \\
(1.250)\end{array}$ & $\begin{array}{l}0.210 \\
1.728\end{array}$ \\
\hline SIZE & $\begin{array}{c}0.004 \\
(3.990)^{* * *}\end{array}$ & $\begin{array}{c}<0.0001 \\
2.323\end{array}$ & $\begin{array}{c}0.005 \\
(4.210)^{* * *}\end{array}$ & $\begin{array}{c}<0.0001 \\
2.363\end{array}$ & $\begin{array}{c}0.004 \\
(3.420)^{* * *}\end{array}$ & $\begin{array}{l}0.001 \\
2.471\end{array}$ \\
\hline LEV & $\begin{array}{l}-0.009 \\
(-1.410)\end{array}$ & $\begin{array}{l}0.157 \\
1.969\end{array}$ & $\begin{array}{c}-0.015 \\
(-2.580)^{* *}\end{array}$ & $\begin{array}{l}0.010 \\
1.412\end{array}$ & $\begin{array}{c}-0.010 \\
(-1.460)\end{array}$ & $\begin{array}{l}0.143 \\
1.972\end{array}$ \\
\hline LOSSDUM & $\begin{array}{l}-0.002 \\
(0.550)\end{array}$ & $\begin{array}{l}0.585 \\
1.205\end{array}$ & $\begin{array}{l}-0.003 \\
(0.890)\end{array}$ & $\begin{array}{l}0.371 \\
1.140\end{array}$ & $\begin{array}{c}-0.002 \\
(-0.570)\end{array}$ & $\begin{array}{l}0.566 \\
1.206\end{array}$ \\
\hline TA & $\begin{array}{c}-0.051 \\
(7.970) * * *\end{array}$ & $\begin{array}{c}<0.0001 \\
1.510\end{array}$ & $\begin{array}{c}-0.050 \\
(7.680) * * *\end{array}$ & $\begin{array}{c}<0.0001 \\
1.528\end{array}$ & $\begin{array}{c}-0.050 \\
(-7.850)^{* * *}\end{array}$ & $\begin{array}{c}<0.0001 \\
1.520\end{array}$ \\
\hline STD_OCF & $\begin{array}{c}-0.019 \\
(-1.300)\end{array}$ & $\begin{array}{l}0.195 \\
1.194\end{array}$ & $\begin{array}{c}-0.009 \\
(-0.620)\end{array}$ & $\begin{array}{l}0.536 \\
1.194\end{array}$ & $\begin{array}{c}-0.019 \\
(-1.290)\end{array}$ & $\begin{array}{l}0.199 \\
1.194\end{array}$ \\
\hline AGE & $\begin{array}{c}0.001 \\
(0.890)\end{array}$ & $\begin{array}{l}0.375 \\
1.140\end{array}$ & $\begin{array}{c}0.001 \\
(0.160)\end{array}$ & $\begin{array}{l}0.870 \\
1.131\end{array}$ & $\begin{array}{c}0.001 \\
(0.890)\end{array}$ & $\begin{array}{l}0.375 \\
1.138\end{array}$ \\
\hline SLACK & $\begin{array}{c}-0.014 \\
(-0.770)\end{array}$ & $\begin{array}{l}0.442 \\
1.198\end{array}$ & $\begin{array}{c}-0.029 \\
(-1.380)\end{array}$ & $\begin{array}{l}0.167 \\
1.104\end{array}$ & $\begin{array}{c}-0.014 \\
(-0.750)\end{array}$ & $\begin{array}{l}0.453 \\
1.195\end{array}$ \\
\hline OWN & $\begin{array}{c}-0.017 \\
(-2.360)\end{array}$ & $\begin{array}{l}0.019 \\
1.219\end{array}$ & $\begin{array}{c}-0.016 \\
(-2.120)\end{array}$ & $\begin{array}{l}0.035 \\
1.223\end{array}$ & $\begin{array}{c}-0.017 \\
(-2.270)\end{array}$ & $\begin{array}{l}0.023 \\
1.221\end{array}$ \\
\hline FOR & $\begin{array}{l}-0.015 \\
(-1.470)\end{array}$ & $\begin{array}{l}0.142 \\
1.796\end{array}$ & $\begin{array}{c}-0.013 \\
(-1.240)\end{array}$ & $\begin{array}{l}0.214 \\
1.812\end{array}$ & $\begin{array}{c}-0.015 \\
(-1.460)\end{array}$ & $\begin{array}{l}0.143 \\
1.795\end{array}$ \\
\hline BIG4 & $\begin{array}{c}-0.002 \\
(-0.830)\end{array}$ & $\begin{array}{l}0.407 \\
1.279\end{array}$ & $\begin{array}{c}-0.003 \\
(-1.000)\end{array}$ & $\begin{array}{l}0.318 \\
1.281\end{array}$ & $\begin{array}{c}-0.002 \\
(-0.820)\end{array}$ & $\begin{array}{l}0.411 \\
1.279\end{array}$ \\
\hline YD & Included & & Included & & Included & \\
\hline ID & Included & & Included & & Included & \\
\hline F-VALUE & $10.56^{* * *}$ & & $10.51 * * *$ & & $10.61^{* * *}$ & \\
\hline ADJ R-SQ & $8.36 \%$ & & $8.60 \%$ & & $8.40 \%$ & \\
\hline
\end{tabular}

Notes: (1) This table presents the results from regressing debt origin on investment efficiency for overinvestment sample. Models 1, 2, and 3 are classified as follows. Model 1 scaled public and private debts to total assets, and model 2 scaled public and private debts to the sum of public and private debts. Model 3 looks at public debt as a dummy variable rather than a continuous variable. (2) Please refer to Section 3.2 for variable definitions. (3) ***,**** denote significance at the $1 \%, 5 \%$, and $10 \%$ levels, respectively (two-tailed).

Table 7 shows the results of the regression analysis of Equations (1)-(3) on the relationship between debt origin and investment efficiency for the underinvestment sample. In Model 1, the LOANR and the investment efficiency were significant in the negative direction at the $10 \%$ level. BONDR and investment efficiency were significant in the positive direction at the $1 \%$ level. Firms that have sourced a lot of financing by issuing public debt are highly efficient.

In Model 2, BOND_LOANR and investment efficiency were significant in the positive direction at the $1 \%$ level. This means that the higher the funding ratio through public debt, the higher the investment efficiency. In Model 3, LOANR and investment efficiency were significant in the negative direction at the $10 \%$ level, and BONDDUM and investment efficiency were positively significant at the $1 \%$ level. This means that firms that have sourced a large amount of financing through loans, which are private debt, have low investment efficiency. Firms that have sourced a lot of financing by issuing public debt are highly efficient. 
Table 7. Debt origin and investment efficiency: underinvestment sample $(n=4956)$.

\begin{tabular}{|c|c|c|c|c|c|c|}
\hline \multirow[b]{2}{*}{ Variables } & \multicolumn{2}{|c|}{ Model 1} & \multicolumn{2}{|c|}{ Model 2} & \multicolumn{2}{|c|}{ Model 3} \\
\hline & $\begin{array}{c}\text { Coeff. } \\
\text { (t-Value) }\end{array}$ & $\begin{array}{c}p \text {-Value } \\
\text { VIF }\end{array}$ & $\begin{array}{c}\text { Coeff. } \\
\text { (t-Value) }\end{array}$ & $\begin{array}{c}p \text {-Value } \\
\text { VIF }\end{array}$ & $\begin{array}{c}\text { Coeff. } \\
\text { (t-Value) }\end{array}$ & $\begin{array}{c}p \text {-Value } \\
\text { VIF }\end{array}$ \\
\hline INTERCEPT & $\begin{array}{c}0.182 \\
(6.700)^{* * *}\end{array}$ & $\begin{array}{c}<0.0001 \\
0.000\end{array}$ & $\begin{array}{c}0.169 \\
(5.910)^{* * *}\end{array}$ & $\begin{array}{c}<0.0001 \\
0.000\end{array}$ & $\begin{array}{c}0.217 \\
(7.750) *\end{array}$ & $\begin{array}{c}<0.0001 \\
0.000\end{array}$ \\
\hline LOANR & $\begin{array}{c}-0.014 \\
(-1.760)\end{array}$ & $\begin{array}{l}0.080 \\
2.236\end{array}$ & & & $\begin{array}{c}-0.016 \\
(-1.750)^{*}\end{array}$ & $\begin{array}{l}0.080 \\
2.200\end{array}$ \\
\hline BONDR & $\begin{array}{c}0.144 \\
(6.060)^{* * *}\end{array}$ & $\begin{array}{c}<0.0001 \\
1.365\end{array}$ & & & & \\
\hline BOND_LOANR & & & $\begin{array}{c}0.064 \\
(5.740)^{* * *}\end{array}$ & $\begin{array}{c}<0.0001 \\
1.283\end{array}$ & & \\
\hline BONDDUM & & & & & $\begin{array}{c}0.023 \\
(7.850)^{* * *}\end{array}$ & $\begin{array}{c}<0.0001 \\
1.557\end{array}$ \\
\hline SIZE & $\begin{array}{c}-0.012 \\
(-11.200)^{* * *}\end{array}$ & $\begin{array}{c}<0.0001 \\
1.807\end{array}$ & $\begin{array}{c}-0.011 \\
(-10.250)^{* * *}\end{array}$ & $\begin{array}{c}<0.0001 \\
1.896\end{array}$ & $\begin{array}{c}-0.013 \\
(-12.170)^{* * *}\end{array}$ & $\begin{array}{c}<0.0001 \\
1.947\end{array}$ \\
\hline LEV & $\begin{array}{c}0.029 \\
(4.500)^{* * *}\end{array}$ & $\begin{array}{c}<0.0001 \\
2.059\end{array}$ & $\begin{array}{c}0.027 \\
(4.870)^{* * *}\end{array}$ & $\begin{array}{c}<0.0001 \\
1.385\end{array}$ & $\begin{array}{c}0.027 \\
(4.200) * * *\end{array}$ & $\begin{array}{c}<0.0001 \\
2.061\end{array}$ \\
\hline LOSSDUM & $\begin{array}{c}-0.027 \\
(-9.280)^{* * *}\end{array}$ & $\begin{array}{c}<0.0001 \\
1.206\end{array}$ & $\begin{array}{c}-0.028 \\
(-9.600)^{* * *}\end{array}$ & $\begin{array}{c}<0.0001 \\
1.137\end{array}$ & $\begin{array}{c}-0.027 \\
(-9.250)^{* * *}\end{array}$ & $\begin{array}{c}<0.0001 \\
1.206\end{array}$ \\
\hline TA & $\begin{array}{c}0.011 \\
(1.770) *\end{array}$ & $\begin{array}{l}0.076 \\
1.456\end{array}$ & $\begin{array}{c}0.010 \\
(1.500)\end{array}$ & $\begin{array}{l}0.133 \\
1.454\end{array}$ & $\begin{array}{c}0.013 \\
(2.120)^{* *}\end{array}$ & $\begin{array}{l}0.034 \\
1.458\end{array}$ \\
\hline STD_OCF & $\begin{array}{c}0.126 \\
(8.590)^{* * *}\end{array}$ & $\begin{array}{c}<0.0001 \\
1.162\end{array}$ & $\begin{array}{c}0.128 \\
(8.390)^{* * *}\end{array}$ & $\begin{array}{c}<0.0001 \\
1.159\end{array}$ & $\begin{array}{c}0.127 \\
(8.660)^{* * *}\end{array}$ & $\begin{array}{c}<0.0001 \\
1.162\end{array}$ \\
\hline AGE & $\begin{array}{c}-0.008 \\
(-5.960)^{* * *}\end{array}$ & $\begin{array}{c}<0.0001 \\
1.108\end{array}$ & $\begin{array}{c}-0.007 \\
(-5.100)\end{array}$ & $\begin{array}{c}<0.0001 \\
1.099\end{array}$ & $\begin{array}{c}-0.009 \\
(-6.210)^{* * *}\end{array}$ & $\begin{array}{c}<0.0001 \\
1.106\end{array}$ \\
\hline SLACK & $\begin{array}{c}-0.065 \\
(-3.320)^{* * *}\end{array}$ & $\begin{array}{l}0.001 \\
1.191\end{array}$ & $\begin{array}{c}-0.073 \\
(-3.510)^{* * *}\end{array}$ & $\begin{array}{l}0.000 \\
1.117\end{array}$ & $\begin{array}{c}-0.060 \\
(-3.100)^{* * *}\end{array}$ & $\begin{array}{l}0.002 \\
1.185\end{array}$ \\
\hline OWN & $\begin{array}{c}-0.028 \\
(-3.690) * * *\end{array}$ & $\begin{array}{l}0.000 \\
1.204\end{array}$ & $\begin{array}{c}-0.026 \\
(-3.390) * * *\end{array}$ & $\begin{array}{l}0.001 \\
1.210\end{array}$ & $\begin{array}{c}-0.024 \\
(-3.240)^{* * *}\end{array}$ & $\begin{array}{l}0.001 \\
1.210\end{array}$ \\
\hline FOR & $\begin{array}{c}0.043 \\
(4.130)^{* * *}\end{array}$ & $\begin{array}{c}<0.0001 \\
1.497\end{array}$ & $\begin{array}{c}0.037 \\
(3.330)^{* * *}\end{array}$ & $\begin{array}{l}0.001 \\
1.483\end{array}$ & $\begin{array}{c}0.046 \\
(4.430)^{* * *}\end{array}$ & $\begin{array}{c}<0.0001 \\
1.498\end{array}$ \\
\hline BIG4 & $\begin{array}{c}0.002 \\
(0.840)\end{array}$ & $\begin{array}{l}0.401 \\
1.244\end{array}$ & $\begin{array}{c}0.002 \\
(0.680)\end{array}$ & $\begin{array}{l}0.680 \\
1.243\end{array}$ & $\begin{array}{c}0.002 \\
(0.820)\end{array}$ & $\begin{array}{l}0.412 \\
1.244\end{array}$ \\
\hline YD & Included & & Included & & Included & \\
\hline ID & Included & & Included & & Included & \\
\hline F-VALUE & $42.32 * * *$ & & $40.28^{* * *}$ & & $43.22 * * *$ & \\
\hline ADJ R-SQ & $20.76 \%$ & & $20.51 \%$ & & $21.11 \%$ & \\
\hline
\end{tabular}

Notes: (1) This table presents the results from regressing debt origin on investment efficiency for the underinvestment sample. Models 1, 2, and 3 are classified as follows. Model 1 scaled public and private debts to total assets, and model 2 scaled public and private debts to the sum of public and private debts. Model 3 looks at public debt as a dummy variable rather than a continuous variable. (2) Please refer to Section 3.2 for variable definitions. (3) ***,**** denote significance at the $1 \%, 5 \%$, and $10 \%$ levels, respectively (two-tailed).

As mentioned above, the relationship between debt origin and investment efficiency was lower in the firms with higher financing through loan, and the more efficient with the financing through bonds. In addition, it can be seen that only the regression analysis results of the total sample and the underinvestment sample are statistically strong. This result shows that the relationship between debt origin and investment efficiency may be differentiated by overinvestment and underinvestment sample. The cause of overinvestment is moral hazard, which is an act of selecting an investment plan that can bring high profit even if the probability of profit creation is low. On the other hand, the cause of underinvestment is reverse selection, so that the capital supplier is ex-post because it is possible to limit the capital supply in advance. Inferring the cause of the occurrence, it is considered that the benefit obtained by increasing the earnings quality in relation to debt characteristics and investment efficiency can reduce the reverse selection. 


\subsection{Robustness Analysis}

In the sample, there are companies that raise funds by using both private and public liabilities, so it is necessary to examine the investment efficiency based on the relative weight between the means of debt origin. Table 8 shows the result of further analysis of the hypothesis by scaling the debt origin to total liabilities (asset-equity) rather than total assets. Panel A, B and C in Table 8 show the regression analysis results for the total sample, the overinvestment sample and the underinvestment sample, respectively. The analysis results are similar to Table 5, which supports the hypothesis even when scaled by total liabilities rather than total assets. As a result of the analysis, when scaled to total liabilities, it can be seen that the relative weight has an effect on the significance of the difference.

Table 8. Debt origin and investment efficiency: analysis results scaled to total liabilities instead of total assets.

\begin{tabular}{|c|c|c|c|}
\hline \multicolumn{4}{|c|}{ Panel A: Total Sample } \\
\hline & Model 1 & Model 2 & Model 3 \\
\hline Variables & $\begin{array}{c}\text { Coeff. } \\
\text { (t-Value) }\end{array}$ & $\begin{array}{c}\text { Coeff. } \\
\text { (t-Value) }\end{array}$ & $\begin{array}{c}\text { Coeff. } \\
\text { (t-Value) }\end{array}$ \\
\hline INTERCEPT & $\begin{array}{c}0.062 \\
(3.080) * * *\end{array}$ & $\begin{array}{c}0.035 \\
(1.810) *\end{array}$ & $\begin{array}{c}0.060 \\
(3.000)^{* * *}\end{array}$ \\
\hline LOANR & $\begin{array}{c}-0.010 \\
(-2.340)\end{array}$ & $\begin{array}{c}-0.004 \\
(-0.910)\end{array}$ & \\
\hline BONDR & $\begin{array}{c}0.046 \\
(4.820)^{* * *}\end{array}$ & & $\begin{array}{c}0.039 \\
(4.320)^{* * *}\end{array}$ \\
\hline SIZE & $\begin{array}{c}-0.006 \\
(-8.080)^{* * *}\end{array}$ & $\begin{array}{c}-0.005 \\
(-6.990) * * *\end{array}$ & $\begin{array}{c}-0.006 \\
(-8.130) * * *\end{array}$ \\
\hline LEV & $\begin{array}{c}0.019 \\
(4.400)^{* * *}\end{array}$ & $\begin{array}{c}0.019 \\
(4.440) * *\end{array}$ & $\begin{array}{c}0.015 \\
(3.860)^{* * *}\end{array}$ \\
\hline LOSSDUM & $\begin{array}{c}-0.019 \\
(-8.460)^{* * *}\end{array}$ & $\begin{array}{c}-0.019 \\
(-8.470)^{* * *}\end{array}$ & $\begin{array}{c}-0.019 \\
(-8.880) * * *\end{array}$ \\
\hline TA & $\begin{array}{c}-0.008 \\
(-1.750) *\end{array}$ & $\begin{array}{c}-0.008 \\
(-1.760)\end{array}$ & $\begin{array}{c}-0.008 \\
(-1.840) *\end{array}$ \\
\hline STD_OCF & $\begin{array}{c}0.082 \\
(7.590)^{* * *}\end{array}$ & $\begin{array}{c}0.083 \\
(7.620) * * *\end{array}$ & $\begin{array}{c}0.083 \\
(7.680)^{* * *}\end{array}$ \\
\hline AGE & $\begin{array}{c}-0.005 \\
(-4.890) * * *\end{array}$ & $\begin{array}{c}-0.005 \\
(-5.310) * * *\end{array}$ & $\begin{array}{c}-0.005 \\
(-5.010) * * *\end{array}$ \\
\hline SLACK & $\begin{array}{c}-0.042 \\
(-2.930)^{* * *}\end{array}$ & $\begin{array}{c}-0.037 \\
(-2.590) * *\end{array}$ & $\begin{array}{c}-0.035 \\
(-2.500)\end{array}$ \\
\hline OWN & $\begin{array}{c}-0.025 \\
(-4.590) * * *\end{array}$ & $\begin{array}{c}-0.027 \\
(-4.830) * * *\end{array}$ & $\begin{array}{c}-0.025 \\
(-4.530) * * *\end{array}$ \\
\hline FOR & $\begin{array}{c}0.024 \\
(3.140)^{* * *}\end{array}$ & $\begin{array}{c}0.025 \\
(-3.330) * * *\end{array}$ & $\begin{array}{c}0.027 \\
(3.660) * * *\end{array}$ \\
\hline BIG4 & $\begin{array}{c}0.001 \\
(0.560)\end{array}$ & $\begin{array}{c}0.001 \\
(0.590)\end{array}$ & $\begin{array}{c}0.001 \\
(0.610)\end{array}$ \\
\hline YD & Included & Included & Included \\
\hline ID & Included & Included & Included \\
\hline F-VALUE & $42.84^{* * *}$ & $43.32 * * *$ & $43.92^{* * *}$ \\
\hline ADJ R-SQ & $13.75 \%$ & $13.54 \%$ & $13.70 \%$ \\
\hline \multicolumn{4}{|c|}{ Panel B: Overinvestment Sample } \\
\hline & Model 1 & Model 2 & Model 3 \\
\hline Variables & $\begin{array}{c}\text { Coeff. } \\
\text { (t-Value) }\end{array}$ & $\begin{array}{c}\text { Coeff. } \\
\text { (t-Value) }\end{array}$ & $\begin{array}{c}\text { Coeff. } \\
\text { (t-Value) }\end{array}$ \\
\hline
\end{tabular}


Table 8. Cont.

\begin{tabular}{|c|c|c|c|}
\hline INTERCEPT & $\begin{array}{c}-0.160 \\
(-5.930)^{* * *}\end{array}$ & $\begin{array}{c}-0.159 \\
(-6.150)\end{array}$ & $\begin{array}{c}-0.161 \\
(-5.940) * * *\end{array}$ \\
\hline LOANR & $\begin{array}{c}-0.008 \\
(-1.470)\end{array}$ & $\begin{array}{c}-0.009 \\
(-1.610)\end{array}$ & \\
\hline BONDR & $\begin{array}{c}-0.003 \\
(-0.210)\end{array}$ & & $\begin{array}{c}-0.008 \\
(-0.700)\end{array}$ \\
\hline SIZE & $\begin{array}{c}0.004 \\
(4.190)^{* * *}\end{array}$ & $\begin{array}{c}0.004 \\
(4.340)^{* * *}\end{array}$ & $\begin{array}{c}0.004 \\
(4.130)^{* * *}\end{array}$ \\
\hline LEV & $\begin{array}{c}-0.010 \\
(-1.700)\end{array}$ & $\begin{array}{c}-0.010 \\
(-1.710)^{* *}\end{array}$ & $\begin{array}{c}-0.013 \\
(-2.260)\end{array}$ \\
\hline LOSSDUM & $\begin{array}{c}-0.002 \\
(-0.590)\end{array}$ & $\begin{array}{l}-0.002 \\
(0.590)\end{array}$ & $\begin{array}{c}-0.002 \\
(-0.790)\end{array}$ \\
\hline TA & $\begin{array}{c}-0.050 \\
(-7.910)^{* * *}\end{array}$ & $\begin{array}{c}-0.050 \\
(-7.910)^{* * *}\end{array}$ & $\begin{array}{c}-0.050 \\
(-7.920) * * *\end{array}$ \\
\hline STD_OCF & $\begin{array}{c}-0.019 \\
(-1.310)\end{array}$ & $\begin{array}{c}-0.019 \\
(-1.300)\end{array}$ & $\begin{array}{c}-0.019 \\
(-1.280)\end{array}$ \\
\hline AGE & $\begin{array}{c}0.001 \\
(0.910)\end{array}$ & $\begin{array}{c}0.001 \\
(0.920)\end{array}$ & $\begin{array}{c}0.001 \\
(0.830)\end{array}$ \\
\hline SLACK & $\begin{array}{c}-0.016 \\
(-0.850)\end{array}$ & $\begin{array}{c}-0.016 \\
(-0.860)\end{array}$ & $\begin{array}{c}-0.010 \\
(-0.540)\end{array}$ \\
\hline OWN & $\begin{array}{c}-0.018 \\
(-2.410)^{* *}\end{array}$ & $\begin{array}{c}-0.018 \\
(-2.400)\end{array}$ & $\begin{array}{c}-0.017 \\
(-2.350)\end{array}$ \\
\hline FOR & $\begin{array}{c}-0.015 \\
(-1.540)\end{array}$ & $\begin{array}{c}-0.015 \\
(-1.550)\end{array}$ & $\begin{array}{c}-0.013 \\
(-1.300)\end{array}$ \\
\hline BIG4 & $\begin{array}{c}-0.002 \\
(-0.880)\end{array}$ & $\begin{array}{c}-0.002 \\
(-0.880)\end{array}$ & $\begin{array}{c}-0.002 \\
(-0.790)\end{array}$ \\
\hline YD & Included & Included & Included \\
\hline ID & Included & Included & Included \\
\hline F-VALUE & $10.61^{* * *}$ & $10.92 * * *$ & $10.85^{* * *}$ \\
\hline ADJ R-SQ & $8.40 \%$ & $8.42 \%$ & $8.37 \%$ \\
\hline \multicolumn{4}{|c|}{ Panel C: Underinvestment Sample } \\
\hline & Model 1 & Model 2 & Model 3 \\
\hline Variables & $\begin{array}{c}\text { Coeff. } \\
\text { (t-Value) }\end{array}$ & $\begin{array}{c}\text { Coeff. } \\
\text { (t-Value) }\end{array}$ & $\begin{array}{c}\text { Coeff. } \\
\text { (t-Value) }\end{array}$ \\
\hline INTERCEPT & $\begin{array}{c}0.175 \\
(6.440)^{* * *}\end{array}$ & $\begin{array}{c}0.140 \\
(5.310)^{* *}\end{array}$ & $\begin{array}{c}0.172 \\
(6.340)^{* * *}\end{array}$ \\
\hline LOANR & $\begin{array}{c}-0.010 \\
(-1.750)\end{array}$ & $\begin{array}{c}-0.002 \\
(-0.270)\end{array}$ & \\
\hline BONDR & $\begin{array}{c}0.067 \\
(5.030)^{* *}\end{array}$ & & $\begin{array}{c}0.060 \\
(4.720)^{* * *}\end{array}$ \\
\hline SIZE & $\begin{array}{c}-0.011 \\
(-10.900)^{* * *}\end{array}$ & $\begin{array}{c}-0.010 \\
(-9.910)^{* * *}\end{array}$ & $\begin{array}{c}-0.011 \\
(-10.890)^{* * *}\end{array}$ \\
\hline LEV & $\begin{array}{c}0.030 \\
(5.390)\end{array}$ & $\begin{array}{c}0.030 \\
(5.400) * *\end{array}$ & $\begin{array}{c}0.027 \\
(5.100)^{* * *}\end{array}$ \\
\hline LOSSDUM & $\begin{array}{c}-0.027 \\
(-9.270)\end{array}$ & $\begin{array}{c}-0.027 \\
(-9.260)\end{array}$ & $\begin{array}{c}-0.027 \\
(-9.630) * * *\end{array}$ \\
\hline TA & $\begin{array}{c}0.011 \\
(1.840)^{* * *}\end{array}$ & $\begin{array}{c}0.011 \\
(1.810) *\end{array}$ & $\begin{array}{c}0.011 \\
(1.750) *\end{array}$ \\
\hline STD_OCF & $\begin{array}{c}0.127 \\
(8.600)\end{array}$ & $\begin{array}{c}0.128 \\
(8.670)^{* * *}\end{array}$ & $\begin{array}{c}0.128 \\
(8.710)^{* * *}\end{array}$ \\
\hline AGE & $\begin{array}{c}-0.008 \\
(-5.990)\end{array}$ & $\begin{array}{c}-0.009 \\
(-6.230) * * *\end{array}$ & $\begin{array}{c}-0.008 \\
(-6.060)\end{array}$ \\
\hline
\end{tabular}


Table 8. Cont

\begin{tabular}{cccc}
\hline SLACK & $\begin{array}{c}-0.066 \\
(-3.400)\end{array}$ & $\begin{array}{c}-0.058 \\
(-2.980)^{* * *}\end{array}$ & $\begin{array}{c}-0.059 \\
(-3.120)^{* * *}\end{array}$ \\
\hline \multirow{2}{*}{ OWN } & $\begin{array}{c}-0.028 \\
(-3.730)^{* *}\end{array}$ & $\begin{array}{c}-0.029 \\
(-3.890)^{* * *}\end{array}$ & $\begin{array}{c}-0.028 \\
(-3.700)^{* * *}\end{array}$ \\
\hline \multirow{2}{*}{ FOR } & 0.041 & 0.043 & 0.045 \\
& $(3.960)$ & $(4.070)^{* * *}$ & $(4.390)^{* * *}$ \\
\hline \multirow{2}{*}{ BIG4 } & 0.002 & 0.002 & 0.002 \\
& $(0.820)$ & $(0.840)$ & $(0.820)$ \\
\hline YD & Included & Included & Included \\
\hline ID & Included & Included & Included \\
\hline F-VALUE & $41.91 * * *$ & $42.21^{* * *}$ & $43.03 * * *$ \\
\hline ADJ R-SQ & $20.59 \%$ & $20.24 \%$ & $20.56 \%$ \\
\hline
\end{tabular}

Notes: (1) This table presents the analysis results scaled to total liabilities instead of total assets from regressing debt origin on investment efficiency. Models 1, 2, and 3 are classified as follows. Model 1 scaled public and private debts to total assets, and model 2 scaled public and private debts to the sum of public and private debts. Model 3 looks at public debt as a dummy variable rather than a continuous variable. (2) Please refer to Section 3.2 for variable definitions. (3) $* * * * *, *$ denote significance at the $1 \%, 5 \%$, and $10 \%$ levels, respectively (two-tailed).

Table 9 shows the results of further analysis of the hypotheses by applying the model using the $t-1$ year rather than the $t$ year. Panels A, B and C in Table 9 show the regression analysis results for the total sample, the overinvestment sample and the underinvestment sample, respectively. The results of the analysis showed that only public debt was significant in Model 1, Model 2 and Model 3.

Table 9. Debt origin and investment efficiency: analysis result for time difference model.

\begin{tabular}{|c|c|c|c|}
\hline \multicolumn{4}{|c|}{ Panel A: Total Sample } \\
\hline & Model 1 & Model 2 & Model 3 \\
\hline Variables & $\begin{array}{c}\text { Coeff. } \\
\text { (t-Value) }\end{array}$ & $\begin{array}{c}\text { Coeff. } \\
\text { (t-Value) }\end{array}$ & $\begin{array}{c}\text { Coeff. } \\
\text { (t-Value) }\end{array}$ \\
\hline INTERCEPT & $\begin{array}{c}0.067 \\
(3.330)^{* * *}\end{array}$ & $\begin{array}{c}0.055 \\
(2.650)^{* * *}\end{array}$ & $\begin{array}{c}0.086 \\
(-4.190)^{* * *}\end{array}$ \\
\hline LOANR it - 1 & $\begin{array}{c}-0.002 \\
(-0.280)\end{array}$ & & $\begin{array}{c}-0.004 \\
(-0.630)\end{array}$ \\
\hline BONDR it - 1 & $\begin{array}{c}0.093 \\
(5.390)^{* * *}\end{array}$ & & \\
\hline BOND_LOANR it - 1 & & $\begin{array}{c}0.040 \\
(5.040)^{* * *}\end{array}$ & \\
\hline BONDDUM it - 1 & & & $\begin{array}{c}0.014 \\
(6.780)^{* * *}\end{array}$ \\
\hline SIZE & $\begin{array}{c}-0.007 \\
(-8.490)^{* * *}\end{array}$ & $\begin{array}{c}-0.006 \\
(-7.620)^{* * *}\end{array}$ & $\begin{array}{c}-0.007 \\
(-9.260)^{* * * *}\end{array}$ \\
\hline LEV & $\begin{array}{c}0.014 \\
(3.210)^{* * *}\end{array}$ & $\begin{array}{c}0.014 \\
(3.400)^{* * *}\end{array}$ & $\begin{array}{c}0.014 \\
(3.070)^{* * *}\end{array}$ \\
\hline LOSSDUM & $\begin{array}{c}-0.020 \\
(-8.960)^{* * *}\end{array}$ & $\begin{array}{c}-0.020 \\
(-8.830)^{* * *}\end{array}$ & $\begin{array}{c}-0.020 \\
(-9.010)^{* * *}\end{array}$ \\
\hline TA & $\begin{array}{c}-0.008 \\
(-1.750)\end{array}$ & $\begin{array}{c}-0.009 \\
(-1.930)\end{array}$ & $\begin{array}{l}-0.006 \\
(-1.310) \\
\end{array}$ \\
\hline STD_OCF & $\begin{array}{c}0.084 \\
(7.710)^{* * *}\end{array}$ & $\begin{array}{c}0.087 \\
(7.790) * * *\end{array}$ & $\begin{array}{c}0.083 \\
(7.710)^{* * *}\end{array}$ \\
\hline
\end{tabular}


Table 9. Cont

\begin{tabular}{|c|c|c|c|}
\hline AGE & $\begin{array}{c}-0.005 \\
(-5.020) * * *\end{array}$ & $\begin{array}{c}-0.005 \\
(-4.370)^{* * *}\end{array}$ & $\begin{array}{c}-0.005 \\
(-5.270)^{* * *}\end{array}$ \\
\hline SLACK & $\begin{array}{c}-0.033 \\
(-2.360)^{* *}\end{array}$ & $\begin{array}{c}-0.044 \\
(-2.890)^{* *}\end{array}$ & $\begin{array}{c}-0.031 \\
(-2.190) * *\end{array}$ \\
\hline OWN & $\begin{array}{c}-0.024 \\
(-4.410)^{* *}\end{array}$ & $\begin{array}{c}-0.022 \\
(-3.920)^{* * *}\end{array}$ & $\begin{array}{c}-0.023 \\
(-4.120)\end{array}$ \\
\hline FOR & $\begin{array}{c}0.027 \\
(3.630)^{* * *}\end{array}$ & $\begin{array}{c}0.023 \\
(2.830)^{* * *}\end{array}$ & $\begin{array}{c}0.029 \\
(3.820)^{* * *}\end{array}$ \\
\hline BIG4 & $\begin{array}{c}0.001 \\
(0.530)\end{array}$ & $\begin{array}{c}0.001 \\
(0.450)\end{array}$ & $\begin{array}{c}0.001 \\
(0.530)\end{array}$ \\
\hline YD & Included & Included & Included \\
\hline ID & Included & Included & Included \\
\hline F-VALUE & $43.09^{* * *}$ & $41.18^{* * *}$ & $43.65 * * *$ \\
\hline ADJ R-SQ & $13.82 \%$ & $13.72 \%$ & $13.98 \%$ \\
\hline \multicolumn{4}{|c|}{ Panel B: Overinvestment Sample } \\
\hline & Model 1 & Model 2 & Model 3 \\
\hline Variables & $\begin{array}{c}\text { Coeff. } \\
\text { (t-Value) }\end{array}$ & $\begin{array}{c}\text { Coeff. } \\
\text { (t-Value) }\end{array}$ & $\begin{array}{c}\text { Coeff. } \\
\text { (t-Value) }\end{array}$ \\
\hline INTERCEPT & $\begin{array}{c}-0.152 \\
(-5.630)^{* * *} \\
\end{array}$ & $\begin{array}{c}-0.162 \\
(-5.820)^{* * *}\end{array}$ & $\begin{array}{c}-0.145 \\
(-5.250)^{* * *}\end{array}$ \\
\hline LOANR it -1 & $\begin{array}{c}0.003 \\
(0.380) \\
\end{array}$ & & $\begin{array}{c}0.001 \\
(0.150) \\
\end{array}$ \\
\hline BONDR it - 1 & $\begin{array}{c}0.003 \\
(0.110)\end{array}$ & & \\
\hline BOND_LOANR it - 1 & & $\begin{array}{c}-0.011 \\
(-1.070)\end{array}$ & \\
\hline BONDDUM it - 1 & & & $\begin{array}{c}0.002 \\
(0.860) \\
\end{array}$ \\
\hline SIZE & $\begin{array}{c}0.004 \\
(3.770)^{* * *}\end{array}$ & $\begin{array}{c}0.005 \\
(4.220)^{* * *}\end{array}$ & $\begin{array}{c}0.004 \\
(3.410)^{* * *}\end{array}$ \\
\hline LEV & $\begin{array}{c}-0.014 \\
(-2.320)^{* *}\end{array}$ & $\begin{array}{c}-0.016 \\
(-2.760)^{* * *}\end{array}$ & $\begin{array}{c}-0.015 \\
(-2.330)^{* *}\end{array}$ \\
\hline LOSSDUM & $\begin{array}{c}-0.003 \\
(-0.870)\end{array}$ & $\begin{array}{c}-0.002 \\
(-0.780)\end{array}$ & $\begin{array}{c}-0.003 \\
(-0.890)\end{array}$ \\
\hline TA & $\begin{array}{c}-0.050 \\
(-7.840)^{* * *} \\
\end{array}$ & $\begin{array}{c}-0.050 \\
(-7.670)^{* * *}\end{array}$ & $\begin{array}{c}-0.050 \\
(-7.740)^{* * *}\end{array}$ \\
\hline STD_OCF & $\begin{array}{c}-0.018 \\
(-1.260)\end{array}$ & $\begin{array}{c}-0.011 \\
(-0.750)\end{array}$ & $\begin{array}{c}-0.018 \\
(-1.260)\end{array}$ \\
\hline AGE & $\begin{array}{c}0.001 \\
(0.840)\end{array}$ & $\begin{array}{c}0.001 \\
(0.600)\end{array}$ & $\begin{array}{c}0.001 \\
(0.830)\end{array}$ \\
\hline SLACK & $\begin{array}{c}-0.008 \\
(-0.440)\end{array}$ & $\begin{array}{c}-0.031 \\
(-1.490)\end{array}$ & $\begin{array}{c}-0.008 \\
(-0.420)\end{array}$ \\
\hline OWN & $\begin{array}{c}-0.016 \\
(-2.230)^{* *}\end{array}$ & $\begin{array}{c}-0.016 \\
(-2.220) * *\end{array}$ & $\begin{array}{c}-0.016 \\
(-2.170)^{* *}\end{array}$ \\
\hline FOR & $\begin{array}{c}-0.012 \\
(-1.190)\end{array}$ & $\begin{array}{c}-0.014 \\
(-1.310)\end{array}$ & $\begin{array}{c}-0.012 \\
(-1.190)\end{array}$ \\
\hline BIG4 & $\begin{array}{c}-0.002 \\
(-0.770)\end{array}$ & $\begin{array}{c}-0.002 \\
(-0.600)\end{array}$ & $\begin{array}{c}-0.002 \\
(-0.780)\end{array}$ \\
\hline
\end{tabular}


Table 9. Cont.

\begin{tabular}{|c|c|c|c|}
\hline YD & Included & Included & Included \\
\hline ID & Included & Included & Included \\
\hline F-VALUE & $10.53^{* * *}$ & $10.57^{* * *}$ & $10.55^{* * *}$ \\
\hline ADJ R-SQ & $8.34 \%$ & $8.65 \%$ & $8.36 \%$ \\
\hline \multicolumn{4}{|c|}{ Panel C: Underinvestment Sample } \\
\hline & Model 1 & Model 2 & Model 3 \\
\hline Variables & $\begin{array}{c}\text { Coeff. } \\
\text { (t-Value) }\end{array}$ & $\begin{array}{c}\text { Coeff. } \\
\text { (t-Value) }\end{array}$ & $\begin{array}{c}\text { Coeff. } \\
\text { (t-Value) }\end{array}$ \\
\hline INTERCEPT & $\begin{array}{c}0.179 \\
(6.600)^{* * *}\end{array}$ & $\begin{array}{c}0.171 \\
(6.010)^{* * *}\end{array}$ & $\begin{array}{c}0.206 \\
(7.390)^{* * *}\end{array}$ \\
\hline LOANR it - 1 & $\begin{array}{c}-0.005 \\
(-0.540)\end{array}$ & & $\begin{array}{c}-0.008 \\
(-0.920)\end{array}$ \\
\hline BONDR it - 1 & $\begin{array}{c}0.132 \\
(5.660)^{* * *}\end{array}$ & & \\
\hline BOND_LOANR it - 1 & & $\begin{array}{c}0.065 \\
(6.000)^{* * *}\end{array}$ & \\
\hline BONDDUM it -1 & & & $\begin{array}{c}0.020 \\
(6.900)^{* * *}\end{array}$ \\
\hline SIZE & $\begin{array}{c}-0.012 \\
(-11.150)^{* * *}\end{array}$ & $\begin{array}{c}-0.011 \\
(10.420)^{* * *}\end{array}$ & $\begin{array}{c}-0.013 \\
(11.860)^{* * *}\end{array}$ \\
\hline LEV & $\begin{array}{c}0.026 \\
(4.410)^{* * * *}\end{array}$ & $\begin{array}{c}0.026 \\
(4.750)^{* * *}\end{array}$ & $\begin{array}{c}0.026 \\
(4.290)^{* * *}\end{array}$ \\
\hline LOSSDUM & $\begin{array}{c}-0.028 \\
(-9.660)^{* * *}\end{array}$ & $\begin{array}{c}-0.028 \\
(-9.600)^{* * *}\end{array}$ & $\begin{array}{c}-0.028 \\
(-9.720)^{* * * *}\end{array}$ \\
\hline TA & $\begin{array}{c}0.011 \\
(1.770) *\end{array}$ & $\begin{array}{c}0.009 \\
(1.360)\end{array}$ & $\begin{array}{c}0.014 \\
(2.190)^{* *}\end{array}$ \\
\hline STD_OCF & $\begin{array}{c}0.128 \\
(8.710)^{* * *}\end{array}$ & $\begin{array}{c}0.129 \\
(8.440)^{* * *}\end{array}$ & $\begin{array}{c}0.129 \\
(8.780)^{* * *}\end{array}$ \\
\hline AGE & $\begin{array}{c}-0.008 \\
(-6.120)^{* * *}\end{array}$ & $\begin{array}{c}-0.008 \\
(-5.280)\end{array}$ & $\begin{array}{c}-0.009 \\
(-6.390)^{* * * *}\end{array}$ \\
\hline SLACK & $\begin{array}{c}-0.058 \\
(-3.000) * * *\end{array}$ & $\begin{array}{c}-0.059 \\
(-2.860)^{* * *}\end{array}$ & $\begin{array}{c}-0.056 \\
(-2.890)^{* * * *}\end{array}$ \\
\hline OWN & $\begin{array}{c}-0.027 \\
(-3.640)\end{array}$ & $\begin{array}{c}-0.025 \\
(-3.190)^{* * *}\end{array}$ & $\begin{array}{c}-0.025 \\
(-3.280) * * *\end{array}$ \\
\hline FOR & $\begin{array}{c}0.044 \\
(4.240)^{* * *}\end{array}$ & $\begin{array}{c}0.036 \\
(3.280)^{* * *}\end{array}$ & $\begin{array}{c}0.047 \\
(4.530)^{* * *}\end{array}$ \\
\hline BIG4 & $\begin{array}{c}0.002 \\
(0.740) \\
\end{array}$ & $\begin{array}{c}0.002 \\
(0.600) \\
\end{array}$ & $\begin{array}{c}0.002 \\
(0.750) \\
\end{array}$ \\
\hline YD & Included & Included & Included \\
\hline ID & Included & Included & Included \\
\hline F-VALUE & $42.21^{* * *}$ & $40.04^{* * *}$ & $42.77^{* * *}$ \\
\hline ADJ R-SQ & $20.71 \%$ & $20.48 \%$ & $20.94 \%$ \\
\hline
\end{tabular}

Notes: (1) This table presents the time difference model analysis results from regressing debt origin on investment efficiency. Models 1, 2, and 3 are classified as follows. Model 1 scaled public and private debts to total assets, and model 2 scaled public and private debts to the sum of public and private debts. Model 3 looks at public debt as a dummy variable rather than a continuous variable. (2) Please refer to Section 3.2 for variable definitions. (3) ${ }^{* * *}, * *, *$ denote significance at the $1 \%, 5 \%$, and $10 \%$ levels, respectively (two-tailed). 
Table 10 shows results of further analysis using the investment efficiency measured as Biddle et al. (2009). Panels A, B and C in Table 10 show the regression analysis results for the total sample, the overinvestment sample and the underinvestment sample, respectively. The results of the analysis are similar to those in Table 5.

Table 10. Debt origin and investment efficiency: analysis result using the investment efficiency measured as Biddle et al. (2009).

\begin{tabular}{|c|c|c|c|}
\hline \multicolumn{4}{|c|}{ Panel A: Total Sample } \\
\hline & Model 1 & Model 2 & Model 3 \\
\hline Variables & $\begin{array}{c}\text { Coeff. } \\
\text { (t-Value) }\end{array}$ & $\begin{array}{c}\text { Coeff. } \\
\text { (t-Value) }\end{array}$ & $\begin{array}{c}\text { Coeff. } \\
\text { (t-Value) }\end{array}$ \\
\hline INTERCEPT & $\begin{array}{c}-0.109 \\
(-6.680)^{* * *}\end{array}$ & $\begin{array}{c}-0.112 \\
(-6.620)^{* * *}\end{array}$ & $\begin{array}{c}-0.100 \\
(-5.930)^{* * *}\end{array}$ \\
\hline LOANR & $\begin{array}{c}-0.017 \\
(-3.010)^{* * *}\end{array}$ & & $\begin{array}{c}-0.018 \\
(-3.290)^{* * *}\end{array}$ \\
\hline BONDR & $\begin{array}{c}0.021 \\
(1.500)\end{array}$ & & \\
\hline BOND_LOANR & & $\begin{array}{c}0.004 \\
(0.600)^{* * *} \\
\end{array}$ & \\
\hline BONDDUM & & & $\begin{array}{c}0.004 \\
(2.600)^{* * *}\end{array}$ \\
\hline SIZE & $\begin{array}{c}0.003 \\
(4.190)^{* * *}\end{array}$ & $\begin{array}{c}0.003 \\
(4.270)^{* * *}\end{array}$ & $\begin{array}{c}0.002 \\
(3.460)^{* * *}\end{array}$ \\
\hline LEV & $\begin{array}{c}0.002 \\
(0.400)\end{array}$ & $\begin{array}{c}-0.006 \\
(-1.830)\end{array}$ & $\begin{array}{c}0.001 \\
(0.310)\end{array}$ \\
\hline LOSSDUM & $\begin{array}{c}-0.008 \\
(-4.370)^{* * *}\end{array}$ & $\begin{array}{c}-0.009 \\
(-5.100)\end{array}$ & $\begin{array}{c}-0.008 \\
(-4.390) * * *\end{array}$ \\
\hline TA & $\begin{array}{c}-0.052 \\
(-14.160)^{* * *}\end{array}$ & $\begin{array}{c}-0.051 \\
(-13.550)^{* * *}\end{array}$ & $\begin{array}{c}-0.052 \\
(-13.970)^{* * *}\end{array}$ \\
\hline STD_OCF & $\begin{array}{c}-0.019 \\
(-2.040) * *\end{array}$ & $\begin{array}{c}-0.012 \\
(-1.290)\end{array}$ & $\begin{array}{c}-0.019 \\
(-2.040)^{* * *}\end{array}$ \\
\hline AGE & $\begin{array}{c}-0.001 \\
(-0.750)\end{array}$ & $\begin{array}{c}-0.001 \\
(-1.140)\end{array}$ & $\begin{array}{c}-0.001 \\
(-0.810)\end{array}$ \\
\hline SLACK & $\begin{array}{c}-0.014 \\
(-1.250)\end{array}$ & $\begin{array}{l}-0.019 \\
(-1.490)\end{array}$ & $\begin{array}{c}-0.014 \\
(-1.200)\end{array}$ \\
\hline OWN & $\begin{array}{c}-0.001 \\
(-0.330) \\
\end{array}$ & $\begin{array}{c}0.001 \\
(0.050)\end{array}$ & $\begin{array}{c}-0.001 \\
(-0.210)\end{array}$ \\
\hline FOR & $\begin{array}{c}-0.006 \\
(-1.020) \\
\end{array}$ & $\begin{array}{c}-0.006 \\
(-0.960)\end{array}$ & $\begin{array}{c}-0.006 \\
(-0.940)\end{array}$ \\
\hline BIG4 & $\begin{array}{c}-0.003 \\
(-2.060) * * \\
\end{array}$ & $\begin{array}{c}-0.003 \\
(-2.090)\end{array}$ & $\begin{array}{c}-0.003 \\
(-2.050)^{* *}\end{array}$ \\
\hline YD & Included & Included & Included \\
\hline ID & Included & Included & Included \\
\hline F-VALUE & $27.38^{* * *}$ & $26.58^{* * *}$ & $27.53 * * *$ \\
\hline ADJ R-SQ & $9.78 \%$ & $9.83 \%$ & $9.83 \%$ \\
\hline \multicolumn{4}{|c|}{ Panel B: Overinvestment Sample } \\
\hline & Model 1 & Model 2 & Model 3 \\
\hline Variables & $\begin{array}{c}\text { Coeff. } \\
\text { (t-Value) }\end{array}$ & $\begin{array}{c}\text { Coeff. } \\
\text { (t-Value) }\end{array}$ & $\begin{array}{c}\text { Coeff. } \\
\text { (t-Value) }\end{array}$ \\
\hline INTERCEPT & $\begin{array}{c}-0.175 \\
(-5.950)^{* * *}\end{array}$ & $\begin{array}{c}-0.183 \\
(-6.090)^{* * *}\end{array}$ & $\begin{array}{c}-0.156 \\
(5.150)^{* * *}\end{array}$ \\
\hline
\end{tabular}


Table 10. Cont.

\begin{tabular}{|c|c|c|c|}
\hline LOANR & $\begin{array}{c}-0.013 \\
(-1.230) \\
\end{array}$ & & $\begin{array}{c}-0.017 \\
(1.700) *\end{array}$ \\
\hline BONDR & $\begin{array}{c}0.002 \\
(0.090)\end{array}$ & & \\
\hline BOND_LOANR & & $\begin{array}{c}-0.008 \\
(-0.770)\end{array}$ & \\
\hline BONDDUM & & & $\begin{array}{c}0.005 \\
(1.730)\end{array}$ \\
\hline SIZE & $\begin{array}{c}0.005 \\
(4.260) * * *\end{array}$ & $\begin{array}{c}0.005 \\
(4.650)^{* * *}\end{array}$ & $\begin{array}{c}0.004 \\
(3.460)^{* * *}\end{array}$ \\
\hline LEV & $\begin{array}{c}-0.009 \\
(-1.230)\end{array}$ & $\begin{array}{c}-0.017 \\
(-2.600)^{* * *}\end{array}$ & $\begin{array}{c}-0.009 \\
(-1.260)\end{array}$ \\
\hline LOSSDUM & $\begin{array}{c}-0.002 \\
(-0.620)\end{array}$ & $\begin{array}{l}-0.004 \\
(1.100)\end{array}$ & $\begin{array}{c}-0.002 \\
(-0.660)\end{array}$ \\
\hline TA & $\begin{array}{c}-0.059 \\
(-8.500)^{* * *}\end{array}$ & $\begin{array}{c}-0.058 \\
(-8.270)^{* * *}\end{array}$ & $\begin{array}{c}-0.058 \\
(-8.360)^{* * *}\end{array}$ \\
\hline STD_OCF & $\begin{array}{c}-0.043 \\
(-2.530)^{* *}\end{array}$ & $\begin{array}{c}-0.030 \\
(-1.690) *\end{array}$ & $\begin{array}{c}-0.044 \\
(-2.540)\end{array}$ \\
\hline AGE & $\begin{array}{c}0.001 \\
(0.380)\end{array}$ & $\begin{array}{c}-0.001 \\
(-0.250)\end{array}$ & $\begin{array}{c}0.001 \\
(0.370)\end{array}$ \\
\hline SLACK & $\begin{array}{c}-0.020 \\
(-0.950)\end{array}$ & $\begin{array}{c}-0.041 \\
(-1.820)\end{array}$ & $\begin{array}{c}-0.020 \\
(-0.940)\end{array}$ \\
\hline OWN & $\begin{array}{c}-0.012 \\
(-1.470)\end{array}$ & $\begin{array}{c}-0.012 \\
(-1.480)\end{array}$ & $\begin{array}{c}-0.011 \\
(-1.370)\end{array}$ \\
\hline FOR & $\begin{array}{c}-0.019 \\
(-1.860)\end{array}$ * & $\begin{array}{c}-0.023 \\
(-2.110)\end{array}$ & $\begin{array}{c}-0.019 \\
(-1.820)\end{array}$ \\
\hline BIG4 & $\begin{array}{c}-0.002 \\
(-1.030)\end{array}$ & $\begin{array}{c}-0.003 \\
(-1.170)\end{array}$ & $\begin{array}{c}-0.003 \\
(-1.060)\end{array}$ \\
\hline YD & Included & Included & Included \\
\hline ID & Included & Included & Included \\
\hline F-VALUE & $10.69^{* * *}$ & $10.941^{* * *}$ & $10.78^{* * *}$ \\
\hline ADJ R-SQ & $8.80 \%$ & $9.27 \%$ & $8.88 \%$ \\
\hline \multicolumn{4}{|c|}{ Panel C: Underinvestment Sample } \\
\hline & Model 1 & Model 2 & Model 3 \\
\hline Variables & $\begin{array}{c}\text { Coeff. } \\
\text { (t-Value) }\end{array}$ & $\begin{array}{c}\text { Coeff. } \\
\text { (t-Value) }\end{array}$ & $\begin{array}{c}\text { Coeff. } \\
\text { (t-Value) }\end{array}$ \\
\hline INTERCEPT & $\begin{array}{c}-0.074 \\
(-3.930)\end{array}$ & $\begin{array}{c}-0.074 \\
(-3.740)^{* * *}\end{array}$ & $\begin{array}{c}-0.071 \\
(-3.650) * * *\end{array}$ \\
\hline LOANR & $\begin{array}{c}-0.023 \\
(-3.650) * * * \\
\end{array}$ & & $\begin{array}{c}-0.021 \\
(-3.470)\end{array}$ \\
\hline BONDR & $\begin{array}{c}0.046 \\
(2.880)^{* * *}\end{array}$ & & \\
\hline BOND_LOANR & & $\begin{array}{c}0.020 \\
(2.550)^{* *}\end{array}$ & \\
\hline BONDDUM & & & $\begin{array}{c}0.005 \\
(2.380) * *\end{array}$ \\
\hline SIZE & $\begin{array}{c}0.001 \\
(2.020) * *\end{array}$ & $\begin{array}{c}0.001 \\
(1.750) *\end{array}$ & $\begin{array}{c}0.001 \\
(1.770)\end{array}$ \\
\hline LEV & $\begin{array}{c}0.008 \\
(1.820) *\end{array}$ & $\begin{array}{c}-0.001 \\
(-0.330) \\
\end{array}$ & $\begin{array}{c}0.007 \\
(1.710)\end{array}$ * \\
\hline LOSSDUM & $\begin{array}{c}-0.013 \\
(-6.860)^{* * *} \\
\end{array}$ & $\begin{array}{c}-0.015 \\
(-7.480)^{* * *} \\
\end{array}$ & $\begin{array}{c}-0.013 \\
(-6.850)^{* * *}\end{array}$ \\
\hline
\end{tabular}


Table 10. Cont.

\begin{tabular}{cccc}
\hline \multirow{2}{*}{ TA } & $\begin{array}{c}-0.044 \\
(-10.590)^{* * *}\end{array}$ & $\begin{array}{c}-0.043 \\
(-10.010)^{* * *}\end{array}$ & $\begin{array}{c}-0.043 \\
(-10.430)^{* * *}\end{array}$ \\
\hline \multirow{2}{*}{ STD_OCF } & -0.001 & 0.002 & -0.001 \\
& $(-0.130)$ & $(0.170)$ & $(-0.090)$ \\
\hline \multirow{2}{*}{ AGE } & -0.003 & -0.003 & -0.003 \\
& $(-2.870)^{* * *}$ & $(-2.600)^{* * *}$ & $(-2.980)^{* * *}$ \\
\hline \multirow{2}{*}{ SLACK } & -0.012 & -0.005 & -0.010 \\
& $(-0.970)$ & $(-0.360)$ & $(-0.810)$ \\
\hline \multirow{2}{*}{ OWN } & 0.005 & 0.008 & 0.005 \\
& $(0.910)$ & $(1.550)$ & $(1.000)$ \\
\hline \multirow{2}{*}{ FOR } & 0.008 & 0.011 & 0.008 \\
& $(1.140)$ & $(1.480)$ & $(1.220)$ \\
\hline \multirow{2}{*}{ BIG4 } & -0.003 & -0.003 & -0.003 \\
& $(-1.490)$ & $(-1.620)$ & $(-1.490)$ \\
\hline YD & Included & Included & Included \\
\hline ID & Included & Included & Included \\
\hline F-VALUE & $22.24 * * *$ & $20.68 * * *$ & $22.15 * * *$ \\
\hline ADJ R-SQ & $12.93 \%$ & $12.52 \%$ & $12.89 \%$ \\
\hline
\end{tabular}

Notes: (1) This table presents analysis results from regressing debt origin on investment efficiency measured as in Biddle et al. (2009). The model in Biddle et al. (2009) is as follows. INVEST $i t=\alpha_{0}+\alpha_{1} \mathrm{GRW}_{\mathrm{it}-1}+\varepsilon$. Please refer to Section 3.2 for variable definitions. Models 1,2, and 3 are classified as follows. Model 1 scaled public and private debts to total assets, and model 2 scaled public and private debts to the sum of public and private debts. Model 3 looks at public debt as dummy variable rather than continuous variable. (2) Please refer to Section 3.2 for variable definitions. (3) ${ }^{* * *}, * * *$ denote significance at the $1 \%, 5 \%$, and $10 \%$ levels, respectively (two-tailed).

Table 11 shows the results of further analysis using the methodology of Gow et al. (2010). Gow et al. (2010) proposed a method to use the standard error clustered by firm and year to solve the dependency problem of integrating cross-sectional time series data. In this study, $t$-values were further analyzed using clustered standard errors by firm-year by applying the methodology of Gow et al. (2010). Panels A, B and C in Table 11 show the regression analysis results for the total sample, the overinvestment sample and the underinvestment sample, respectively. The results of the analysis are similar to Table 5, which shows that the study supports the hypotheses even after considering time series dependence and cross-sectional dependence.

Table 11. Debt origin and investment efficiency: analysis results using the methodology of Gow et al. (2010).

\begin{tabular}{cccc}
\hline \multirow{2}{*}{ Variables } & \multicolumn{2}{c}{ Panel A: Total Sample } & \\
& Model 1 & Model 2 & Model 3 \\
\cline { 2 - 4 } & $\begin{array}{c}\text { Coeff. } \\
(\mathbf{t}-\text { Value) }\end{array}$ & $\begin{array}{c}\text { Coeff. } \\
(\mathbf{t}-\text { Value })\end{array}$ & $\begin{array}{c}\text { Coeff. } \\
(\mathbf{t}-\text {-Value) }\end{array}$ \\
\hline \multirow{2}{*}{ INTERCEPT } & 0.069 & 0.057 & 0.096 \\
& $(0.507)$ & $(0.440)$ & $(0.640)$ \\
\hline \multirow{2}{*}{ LOANR } & -0.012 & & -0.015 \\
& $(-2.148)^{* *}$ & $(-2.529)^{* *}$ \\
\hline \multirow{2}{*}{ BONDR } & 0.102 & \\
\hline \multirow{2}{*}{ BOND_LOANR } & $(2.020)^{*}$ & 0.039 & \\
\hline \multirow{2}{*}{ BONDDUM } & & $(1.792)^{*}$ & 0.017 \\
& & & $(1.972)^{*}$ \\
\hline
\end{tabular}


Table 11. Cont.

\begin{tabular}{|c|c|c|c|}
\hline SIZE & $\begin{array}{c}-0.007 \\
(-0.945)\end{array}$ & $\begin{array}{c}-0.006 \\
(-0.911)\end{array}$ & $\begin{array}{c}-0.008 \\
(-1.016)\end{array}$ \\
\hline LEV & $\begin{array}{c}0.018 \\
(1.435)\end{array}$ & $\begin{array}{c}0.015 \\
(0.977)\end{array}$ & $\begin{array}{c}0.016 \\
(1.415)\end{array}$ \\
\hline LOSSDUM & $\begin{array}{c}-0.019 \\
(-2.045)\end{array}$ & $\begin{array}{c}-0.020 \\
(-2.173)\end{array}$ & $\begin{array}{c}-0.019 \\
(-2.059)\end{array}$ \\
\hline TA & $\begin{array}{c}-0.009 \\
(-0.288)\end{array}$ & $\begin{array}{c}-0.009 \\
(-0.323)\end{array}$ & $\begin{array}{c}-0.006 \\
(-0.209)\end{array}$ \\
\hline STD_OCF & $\begin{array}{c}0.082 \\
(1.064)\end{array}$ & $\begin{array}{c}0.087 \\
(1.133)\end{array}$ & $\begin{array}{c}0.083 \\
(1.070)\end{array}$ \\
\hline AGE & $\begin{array}{c}-0.005 \\
(-1.176)\end{array}$ & $\begin{array}{c}-0.005 \\
(-1.209)\end{array}$ & $\begin{array}{c}-0.005 \\
(-1.202)\end{array}$ \\
\hline SLACK & $\begin{array}{c}-0.040 \\
(-1.609)\end{array}$ & $\begin{array}{c}-0.052 \\
(-1.735)\end{array}$ & $\begin{array}{c}-0.036 \\
(-1.592)\end{array}$ \\
\hline OWN & $\begin{array}{c}-0.025 \\
(-1.374)\end{array}$ & $\begin{array}{c}-0.023 \\
(-1.257)\end{array}$ & $\begin{array}{c}-0.023 \\
(-1.361)\end{array}$ \\
\hline FOR & $\begin{array}{c}0.026 \\
(0.988)\end{array}$ & $\begin{array}{c}0.023 \\
(0.973)\end{array}$ & $\begin{array}{c}0.027 \\
(1.023)\end{array}$ \\
\hline BIG4 & $\begin{array}{c}0.001 \\
(0.244) \\
\end{array}$ & $\begin{array}{c}0.001 \\
(0.169) \\
\end{array}$ & $\begin{array}{c}0.001 \\
(0.258) \\
\end{array}$ \\
\hline YD & Included & Included & Included \\
\hline ID & Included & Included & Included \\
\hline F-VALUE & $42.27^{* * *}$ & $40.71^{* * *}$ & $42.51 * * *$ \\
\hline ADJ R-SQ & $14.17 \%$ & $14.10 \%$ & $14.45 \%$ \\
\hline \multicolumn{4}{|c|}{ Panel B: Overinvestment Sample } \\
\hline & Model 1 & Model 2 & Model 3 \\
\hline Variables & $\begin{array}{c}\text { Coeff. } \\
\text { (t-Value) }\end{array}$ & $\begin{array}{c}\text { Coeff. } \\
\text { (t-Value) }\end{array}$ & $\begin{array}{c}\text { Coeff. } \\
\text { (t-Value) }\end{array}$ \\
\hline INTERCEPT & $\begin{array}{c}-0.158 \\
(-4.677)^{* * *} \\
\end{array}$ & $\begin{array}{c}-0.162 \\
(-4.389)^{* * *}\end{array}$ & $\begin{array}{c}-0.146 \\
(-4.261)^{* * *}\end{array}$ \\
\hline LOANR & $\begin{array}{c}-0.010 \\
(-0.857) \\
\end{array}$ & & $\begin{array}{c}-0.013 \\
(-1.049) \\
\end{array}$ \\
\hline BONDR & $\begin{array}{c}0.004 \\
(0.208)\end{array}$ & & \\
\hline BOND_LOANR & & $\begin{array}{c}-0.010 \\
(-1.136) \\
\end{array}$ & \\
\hline BONDDUM & & & $\begin{array}{c}0.004 \\
(1.160)\end{array}$ \\
\hline SIZE & $\begin{array}{c}0.004 \\
(3.559)^{* * *}\end{array}$ & $\begin{array}{c}0.005 \\
(3.491)^{* * *}\end{array}$ & $\begin{array}{c}0.004 \\
(3.178)^{* * *}\end{array}$ \\
\hline LEV & $\begin{array}{c}-0.009 \\
(-1.559)\end{array}$ & $\begin{array}{c}-0.015 \\
(-2.059)\end{array}$ & $\begin{array}{c}-0.010 \\
(-1.627)\end{array}$ \\
\hline LOSSDUM & $\begin{array}{c}-0.002 \\
(-0.498) \\
\end{array}$ & $\begin{array}{c}-0.003 \\
(-0.746) \\
\end{array}$ & $\begin{array}{l}-0.002 \\
(-0.521) \\
\end{array}$ \\
\hline TA & $\begin{array}{c}-0.051 \\
(7.970)^{* * *}\end{array}$ & $\begin{array}{c}-0.050 \\
(-7.578)^{* * *}\end{array}$ & $\begin{array}{c}-0.050 \\
(-7.563) * * *\end{array}$ \\
\hline
\end{tabular}


Table 11. Cont.

\begin{tabular}{|c|c|c|c|}
\hline STD_OCF & $\begin{array}{c}-0.019 \\
(-1.300)\end{array}$ & $\begin{array}{c}-0.009 \\
(-0.597)\end{array}$ & $\begin{array}{c}-0.019 \\
(-1.105)\end{array}$ \\
\hline AGE & $\begin{array}{c}0.001 \\
(0.890)\end{array}$ & $\begin{array}{c}0.001 \\
(0.142)\end{array}$ & $\begin{array}{c}0.001 \\
(0.684)\end{array}$ \\
\hline SLACK & $\begin{array}{c}-0.014 \\
(-0.770)\end{array}$ & $\begin{array}{c}-0.029 \\
(-0.998)\end{array}$ & $\begin{array}{c}-0.014 \\
(-0.598)\end{array}$ \\
\hline OWN & $\begin{array}{c}-0.017 \\
(-2.360)^{* *}\end{array}$ & $\begin{array}{c}-0.016 \\
(-1.926)\end{array}$ & $\begin{array}{c}-0.017 \\
(-2.030)\end{array}$ \\
\hline FOR & $\begin{array}{c}-0.015 \\
(-1.470)\end{array}$ & $\begin{array}{c}-0.013 \\
(-1.290)\end{array}$ & $\begin{array}{c}-0.015 \\
(-1.420)\end{array}$ \\
\hline BIG4 & $\begin{array}{c}-0.002 \\
(-0.830)\end{array}$ & $\begin{array}{c}-0.003 \\
(-1.064)\end{array}$ & $\begin{array}{c}-0.002 \\
(-0.995)\end{array}$ \\
\hline YD & Included & Included & Included \\
\hline ID & Included & Included & Included \\
\hline F-VALUE & $9.16^{* * *}$ & $9.07^{* * *}$ & $9.18^{* * *}$ \\
\hline ADJ R-SQ & $9.24 \%$ & $9.51 \%$ & $9.28 \%$ \\
\hline \multicolumn{4}{|c|}{ Panel C: Underinvestment Sample } \\
\hline & Model 1 & Model 2 & Model 3 \\
\hline Variables & $\begin{array}{c}\text { Coeff. } \\
\text { (t-Value) }\end{array}$ & $\begin{array}{c}\text { Coeff. } \\
\text { (t-Value) }\end{array}$ & $\begin{array}{c}\text { Coeff. } \\
\text { (t-Value) }\end{array}$ \\
\hline INTERCEPT & $\begin{array}{c}0.182 \\
(1.149) \\
\end{array}$ & $\begin{array}{c}0.169 \\
(1.118) \\
\end{array}$ & $\begin{array}{c}0.217 \\
(1.232) \\
\end{array}$ \\
\hline LOANR & $\begin{array}{c}-0.014 \\
(-1.812)\end{array}$ & & $\begin{array}{c}-0.016 \\
(-2.140)^{* *}\end{array}$ \\
\hline BONDR & $\begin{array}{c}0.144 \\
(2.419)^{* *}\end{array}$ & & \\
\hline BOND_LOANR & & $\begin{array}{c}0.064 \\
(2.425) * *\end{array}$ & \\
\hline BONDDUM & & & $\begin{array}{c}0.023 \\
(2.362) * *\end{array}$ \\
\hline SIZE & $\begin{array}{l}-0.012 \\
(1.421) \\
\end{array}$ & $\begin{array}{c}-0.011 \\
(-1.424) \\
\end{array}$ & $\begin{array}{c}-0.013 \\
(-1.466)\end{array}$ \\
\hline LEV & $\begin{array}{c}0.029 \\
(2.262) * *\end{array}$ & $\begin{array}{c}0.027 \\
(1.588) \\
\end{array}$ & $\begin{array}{c}0.027 \\
(2.245) * *\end{array}$ \\
\hline LOSSDUM & $\begin{array}{c}-0.027 \\
(-2.797)^{* *}\end{array}$ & $\begin{array}{c}-0.028 \\
(-3.028)^{* * *}\end{array}$ & $\begin{array}{c}-0.027 \\
(-2.814)^{* *}\end{array}$ \\
\hline TA & $\begin{array}{c}0.011 \\
(0.328) \\
\end{array}$ & $\begin{array}{c}0.010 \\
(0.301)\end{array}$ & $\begin{array}{c}0.013 \\
(0.384) \\
\end{array}$ \\
\hline STD_OCF & $\begin{array}{c}0.126 \\
(1.363) \\
\end{array}$ & $\begin{array}{c}0.128 \\
(1.402)\end{array}$ & $\begin{array}{c}0.127 \\
(1.375) \\
\end{array}$ \\
\hline AGE & $\begin{array}{c}-0.008 \\
(-1.873)\end{array}$ & $\begin{array}{c}-0.007 \\
(-1.753)\end{array}$ & $\begin{array}{c}-0.009 \\
(-1.927)\end{array}$ * \\
\hline SLACK & $\begin{array}{c}-0.065 \\
(-1.721) \\
\end{array}$ & $\begin{array}{c}-0.073 \\
(-1.687) \\
\end{array}$ & $\begin{array}{c}-0.060 \\
(-1.722)\end{array}$ \\
\hline OWN & $\begin{array}{c}-0.028 \\
(-1.214) \\
\end{array}$ & $\begin{array}{c}-0.026 \\
(-1.110) \\
\end{array}$ & $\begin{array}{c}-0.024 \\
(-1.170) \\
\end{array}$ \\
\hline
\end{tabular}


Table 11. Cont.

\begin{tabular}{cccc}
\hline FOR & 0.043 & 0.037 & 0.046 \\
& $(1.564)$ & $(1.562)$ & $(1.607)$ \\
\hline \multirow{2}{*}{ BIG4 } & 0.002 & 0.002 & 0.002 \\
& $(0.362)$ & $(0.305)$ & $(0.352)$ \\
\hline YD & Included & Included & Included \\
\hline ID & Included & Included & Included \\
\hline F-VALUE & $43.06^{* * *}$ & $41.45^{* * *}$ & $43.55^{* * *}$ \\
\hline ADJ R-SQ & $21.26 \%$ & $21.03 \%$ & $21.61 \%$ \\
\hline
\end{tabular}

Notes: (1) This table presents the analysis results using the methodology of Gow et al. (2010) from regressing debt origin on investment efficiency. Models 1,2, and 3 are classified as follows. Model 1 scaled public and private debts to total assets, and model 2 scaled public and private debts to the sum of public and private debts. Model 3 looks at public debt as dummy variable rather than continuous variable. (2) Please refer to Section 3.2 for variable definitions. (3) ${ }^{* * *}, * * *$ denote significance at the $1 \%, 5 \%$, and $10 \%$ levels, respectively (two-tailed).

\subsection{Other Robustness Analysis}

There is a large debate about the changing corporate debt/investment link before and since the global financial crisis of 2007/2008. In Europe for instance, investment dynamics changed significantly after the crisis, and the link between corporate debt holdings and investment activity changed. It would be interesting to see whether a similar difference could be observed in a sample for the debt origin/efficiency link, as financial constraints potentially had a very different effect on investment efficiency after 2008. As a result of dividing and verifying samples before and after the financial crisis, statistical significance was maintained before the financial crisis, but there was no statistical significance after the financial crisis. It can be inferred that the statistical significance of debt characteristics and investment efficiency does not appear due to changes in corporate financial constraints, investment behavior, and accounting information after the financial crisis. Second, our model features year and industry dummies. This model itself has the disadvantage of not being able to measure the characteristics of an individual company, but it can grasp the overall situation of the company through cross-sectional analysis. However, in order to compensate for the shortcomings of cross-sectional analysis, the fixed effect model of individual companies was further analyzed. As a result of the analysis, statistical significance was maintained. Third, listed firms are included in our data set, which have easier access to capital/bond markets and usually depend less on (private) bank funding. For smaller firms/SMEs, results for $\mathrm{H} 1 / \mathrm{H} 2$ could look very different; bank funding could be a less costly source of funding in relative terms. Therefore, we examined differences between large listed firms and SMEs and how the results of this paper would be affected if SMEs were used. As a result of analyzing SMEs and large companies, SMEs did not show statistical significance in relation to debt origin and investment efficiency. Large corporations show statistical significance in the relationship between debt characteristics and investment efficiency. It is inferred that this is due to the difference in financing means and procurement cost depending on the size of company. Finally, In Chen et al. (2011)'s model, the residual was estimated by considering the additional control variables, and investment efficiency was re-verified. As additional control variables, firm size, debt ratio, and profitability were selected to reflect the characteristics of the firm. As a result of re-verification, statistical significance was maintained.

\section{Conclusions}

This study examines the relationship between debt origin and investment efficiency using a sample of 8754 firm-years from 2002 to 2017. Debt origin was classified into public and private debt and investment efficiency was measured by the method of Chen et al. (2011).

Public debt is a firm's financing from a large number of unspecified investors through the capital market. Corporate bonds are the most common form of public debt. Private debt is a contract in which 
financing is achieved through a bilateral contract between creditor and debtor. A typical form of debt is a bank loan. Principal-agent problems exist between firms and investors, and the primary cause of agent problems is information asymmetry. There is a difference between public and private debt in terms of setting up contracts and in post monitoring.

On the other hand, firms seek to maximize firm value by raising funds for efficient management activities. However, there is a possibility of overinvestment or underinvestment because the information asymmetry may occur due to the market imperfection. The cause of overinvestment is moral hazard, which is the act of selecting an investment plan that can produce high returns even if the probability of revenue generation is low. The cause of underinvestment is reverse selection, which allows the capital supplier to limit capital supply in advance. In the following, a firm's underinvestment problem arises. As mentioned above, the degree of information asymmetry and the incentives for improving the quality of accounting information differ between firms and creditors according to whether the debt financing method is procured as a public or private debt. Thus, the impact on the value and sustainability of a firm may be said to differ depending on the debt origin. Therefore, this study empirically analyzes the relationship between debt origin and investment efficiency.

The analysis results of this study are as follows. First, public debt and investment efficiency were significantly correlated in a positive direction, supporting the hypothesis of this study. As a result of dividing the sample into an overinvestment sample and an underinvestment sample, the analysis result was statistically significant in the underinvestment sample. This is in line with previous studies that public debt creditors use their financial statements as the primary source of information for evaluating a firm and require firms to have a high level of financial reporting quality to reduce information asymmetry between firm and creditor (Chun et al. 2011; Givoly et al. 2010). Second, private debt and investment efficiency were significantly correlated in the negative direction, supporting the hypothesis of this study. As a result of dividing the sample into an overinvestment sample and an underinvestment sample, the analysis result was statistically more significant in the underinvestment sample. This means that private debt creditors can dilute information asymmetry problems through monitoring and stringent contract clauses and control potential adverse selection problems (An et al. 2004). Thus, the incentive to improve the quality of financial reporting is relatively inferior to that of public debt.

As mentioned above, the empirical result was lower in investment efficiency for firms with more financing through loans, and more efficient for firms with predominant financing through bonds. In addition, it can be seen that only the regression analysis results of the total sample and the underinvestment sample are statistically strong. This result shows that the relationship between debt origin and investment efficiency can be differentiated by overinvestment and underinvestment samples.

As a further analysis result, according to the research method of Chun et al. (2011), the debt ratio was analyzed by scaling to total liabilities rather than total assets, and the time difference model was further considered. As a result, the robustness of the study was maintained even when scaled to total debt. However, the analysis results using the time difference model showed the same direction, but the statistical significance was somewhat lower. The results were maintained even when the method of measuring investment efficiency was different, and the results were maintained even in the analysis applying the methodology of Gow et al. (2010), considering the cross-sectional time series dependence.

This study is meaningful for examining how investment efficiency varies depending on the debt origin in the information asymmetry between firms and investors. Debt contracts between firms and creditors create information asymmetry due to hidden characteristics and hidden behavior. As a result of information asymmetry incurred at the time of initiating a debt contract, as well as in the post-monitoring process, it is impossible to make an optimal decision not only for corporate positions but also for creditors. The results of this study indirectly suggested that the incentive to improve the quality of accounting information is relatively greater in public debt financing methods by verifying the relationship between debt origin and investment efficiency. The difference in investment efficiency 
depends on the method of debt financing, which ultimately leads to the gap between the optimal investment and the firm's investment, which will also affect the firm's value and the firm's sustainability.

The limitations of this study and further discussing are as follows. In this study, the level variables of public and private debt were set as independent variables as characteristics related to debt contracts, but there are limitations in not considering the hidden contract or hidden behavior. We hope that data on hidden contracts or hidden behavior will be studied in future studies. Second, we assume the link between external financing and investment efficiency to vary across sectors where the degree of market access of firms might vary. However, we have not verified this. Third, we have not estimated the model with interacted sector-year fixed effects to account for sector-specific business cycles. Finally, a single firm in the sample can be in the over- or underinvestment sample for different years, i.e., transition from over- to underinvestment from one year to the other. That opens up discussions on potential strategic dynamic investment decisions firms could take. In other words, over-investment and under-investment strategies may change by time series. In this study, cross-sectional analysis was selected as the main model, not firm-fixed analysis. It would be meaningful to discuss the dynamic investment strategies of each firm in the future. It is thought that the sustainability of the company could be improved by supplementing the above-mentioned limitations and examining future research topics. We look forward to further research into the specific company situation. The result of the study that the difference in investment efficiency according to the debt origin can affect a firm's sustainability is expected to provide important implications not only for managers but also for investors and supervisory institutions.

Author Contributions: Conceptualization, H.J.J. and H.M.O.; Formal analysis, H.J.J.; Methodology, H.M.O.; Visualization, H.J.J.; Writing-original draft, H.J.J.; Writing-review and editing, H.M.O. All authors have read and agreed to the published version of the manuscript.

Funding: This research received no external funding.

Conflicts of Interest: The authors declare no conflict of interest.

\section{Appendix A. Variable Definitions for H1, H2}

Dependent Variables

\begin{tabular}{|c|c|}
\hline INV_EF & $\begin{array}{l}\text { investment efficiency, is measured as was done by Chen et al. (2011) } \\
\text { and is defined as the absolute value of the estimated residual } \\
\text { multiplied by }-1\end{array}$ \\
\hline \multicolumn{2}{|c|}{ Explanatory Variables } \\
\hline BONDR & bond ratio, is measured by dividing bonds by total assets \\
\hline LOANR & loan ratio, is measured by dividing borrowings by total assets \\
\hline BOND_LOAN & $\begin{array}{l}\text { public debt ratio, is measured by dividing public debt by the sum of } \\
\text { public debt and private debt }\end{array}$ \\
\hline BONDDUM & bond dummy variable, which is 1 for firms with bonds and 0 otherwise \\
\hline \multicolumn{2}{|c|}{ Control variables } \\
\hline SIZE & firm's size, natural log of total assets \\
\hline LEV & debt ratio of a firm, measured as liabilities divided by total assets \\
\hline LOSSDUM & loss dummy variable, which is 1 for a loss firm and 0 otherwise \\
\hline TA & $\begin{array}{l}\text { tangible asset ratio, measured as tangible assets divided by total assets } \\
\text { the standard deviation of operating cash flow, measured as the }\end{array}$ \\
\hline STD_OCF & $\begin{array}{l}\text { standard deviation of dividing operating cash flow from the cash flow } \\
\text { statement for five years from } t-4 \text { to } t \text { by the lagged total assets }\end{array}$ \\
\hline AGE & $\begin{array}{l}\text { listing period, measured as the value obtained by taking the natural } \\
\text { logarithm of the age of firm }\end{array}$ \\
\hline SLACK & cash ratio, the ratio of cash divided by total assets \\
\hline OWN & the ownership ratio of major shareholder \\
\hline FOR & the ratio of foreign ownership \\
\hline
\end{tabular}




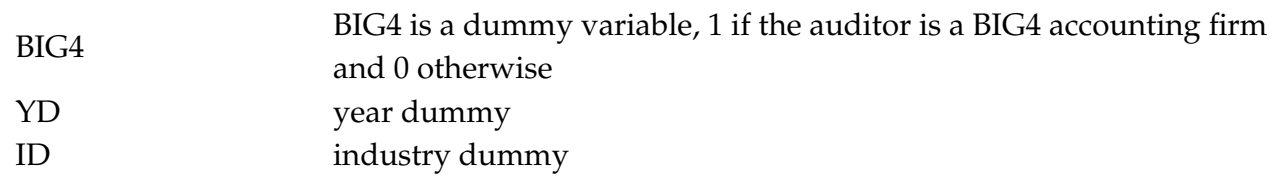

\section{References}

An, Seung-Cheol, Sang-Whi Lee, and Seung-Wook Jang. 2004. A Funding Source Decision of Corporate Bond_Private Placement vs. Public Bond. The Korean Journal of Financial Management 21: 99-123.

Bharath, Sreedhar T., Jayanthi Sunder, and Shyam V. Sunder. 2008. Accounting quality and debt contracting. The Accounting Review 83: 1-28. [CrossRef]

Biddle, Gary C., and Gilles Hilary. 2006. Accounting quality and firm-level capital investment. The Accounting Review 81: 963-82. [CrossRef]

Biddle, Gary C., Gilles Hilary, and Rodrigo S. Verdi. 2009. How does financial reporting quality relate to investments efficiency? Journal of Accounting and Economics 48: 112-31. [CrossRef]

Carey, Mark, Stephen Prowse, John Rea, and Gregory Udell. 1993. The economics of the private placement market. Staff Studies from Board of Governors of the Federal Reserve System (U.S.) 166: 1-111.

Chen, Feng, Ole-Kristian Hope, Qingyuan Li, and Xin Wang. 2011. Financial reporting quality and investment efficiency of private firms in emerging markets. The Accounting Review 86: 1255-88. [CrossRef]

Cho, S. M., and S. A. Kang. 2016. The effect of industry competition intensity on capital investment efficiency. Korea Business Education Research 31: 23-43. [CrossRef]

Chun, Sung-Bin, Hye-Jin Kwon, and Sung-Hye Kim. 2011. Debt financing and earnings management. Study on Accounting, Taxation and Auditing 53: 39-78.

D'Mello, Ranjan, and Mercedes Miranda. 2010. Long-term debt and overinvestment agency problem. Journal of Banking and Finance 34: 324-35. [CrossRef]

Francis, Jennifer, Ryan LaFond, Per M. Olsson, and Katherine Schipper. 2004. Cost of equity and earnings attributes. The Accounting Review 79: 967-1010. [CrossRef]

Francis, Jennifer, Ryan LaFond, Per Olsson, and Katherine Schipper. 2005. The market pricing of accruals quality. Journal of Accounting and Economics 39: 295-327. [CrossRef]

Givoly, Dan, Carla K. Hayn, and Sharon P. Katz. 2010. Does Public Ownership of Equity Improve Earnings Quality? The Accounting Review 85: 195-225. [CrossRef]

Gow, Ian D., Gaizka Ormazabal, and Daniel J. Taylor. 2010. Correcting for Both Cross-sectional and Time-series Dependence in Accounting Research. The Accounting Review 85: 483-512. [CrossRef]

Houston, Joel, and Christopher James. 1996. Bank Information Monopolies and the Mix of Private and Public Debt Claims. Journal of Finance 51: 1863-89. [CrossRef]

Jensen, Michael C. 1986. Agency Costs of Free Cash Flow, Corporate Finance, and Takeovers. American Economic Review 76: 323-29. [CrossRef]

Jung, Hyun-Uk. 2016. A Study on the Relation between Debt Financing and Trading Volume. Accounting Information Research 34: 245-65.

Jung, Hyun-Uk, and Hyun-Ju Lee. 2014. A Study on the Relation between Debt Financing and Foreign Equity. Study on Accounting, Taxation \& Auditing 56: 1-28.

Lee, Se-Yong. 2009. A study on the change in value-relevance of accounting information before and after 1997 financial crisis. Journal of Taxation and Accounting 10: 35-75.

Lee, Bo-Mi, and Won-Sun Paek. 2015. Investment efficiency, earnings persistence, and value relevance. Korean Management Review 44: 1277-304. [CrossRef]

McNichols, Maureen F., and Stephen R. Stubben. 2008. Does earnings management affect firms' investment decisions? The Accounting Review 83: 1571-603. [CrossRef]

Myers, Stewart C. 1977. Determinants of corporate borrowing. Journal of Financial Economics 5: 147-75. [CrossRef]

Park, Bum-Jin. 2013. The Study on the Relation between Debt Characteristics and Audit Fee. Korea Business Education Research 28: 183-209.

Park, Sun-Young, and Han-Soo Bae. 2011. The Effects of Financial Reporting Quality and Corporate Governance on Investment Efficiency. Accounting Information Research 29: 363-91. 
Ramakrishnan, Ram T. S., and Anjan V. Thakor. 1984. Information Reliability and a Theory of Financial Intermediation. The Review of Economic Studies 51: 415-32. [CrossRef]

Richardson, Scott. 2006. Over-investment of free cash flow. Review of Accounting Studies 11: 159-89. [CrossRef] Yeo, Young-Jun, Oh-Jin Kwon, and Sung-Koo Lee. 2015. The Effect of Listing Status and Issuing Public Debt on Financial Reporting Quality: Focus on Small and Medium Business. Accounting Information Research 33: 1-31. 